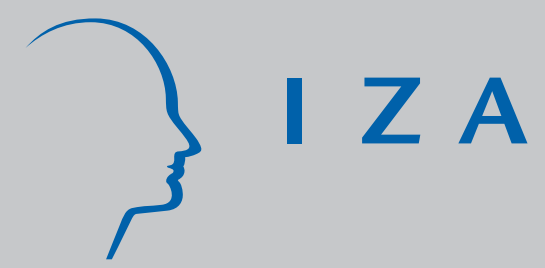

IZA DP No. 5715

Portability of Pension, Health, and Other Social Benefits: Facts, Concepts, Issues

Robert Holzmann

Johannes Koettl

May 2011 


\title{
Portability of Pension, Health, and Other Social Benefits: Facts, Concepts, Issues
}

\author{
Robert Holzmann \\ University of Vienna, \\ World Bank, CES and IZA
}

Johannes Koettl

World Bank and IZA

\section{Discussion Paper No. 5715 \\ May 2011}

IZA

P.O. Box 7240

53072 Bonn

Germany

Phone: +49-228-3894-0

Fax: +49-228-3894-180

E-mail: iza@iza.org

Any opinions expressed here are those of the author(s) and not those of IZA. Research published in this series may include views on policy, but the institute itself takes no institutional policy positions.

The Institute for the Study of Labor (IZA) in Bonn is a local and virtual international research center and a place of communication between science, politics and business. IZA is an independent nonprofit organization supported by Deutsche Post Foundation. The center is associated with the University of Bonn and offers a stimulating research environment through its international network, workshops and conferences, data service, project support, research visits and doctoral program. IZA engages in (i) original and internationally competitive research in all fields of labor economics, (ii) development of policy concepts, and (iii) dissemination of research results and concepts to the interested public.

IZA Discussion Papers often represent preliminary work and are circulated to encourage discussion. Citation of such a paper should account for its provisional character. A revised version may be available directly from the author. 


\section{ABSTRACT \\ Portability of Pension, Health, and Other Social Benefits: Facts, Concepts, Issues}

Portability of social benefits across professions and countries is an increasing concern for individuals and policy makers. Lacking or incomplete transfers of acquired social rights are feared to negatively impact individual labor market decisions as well as capacity to address social risks with consequences for economic and social outcomes. The paper gives a fresh and provocative look on the international perspective of the topic that has so far been dominated by social policy lawyers working within the framework of bilateral agreements; the input by economists has been very limited. It offers an analytical framework for portability analysis that suggests separating the risk pooling, (implicit or actual) pre-funding and redistributive elements in the benefit design and explores the proposed alternative approach for pensions and health care benefits. This promising approach may serve both as a substitute and complement to bi- and multilateral agreements.

JEL Classification: $\quad$ D91, F22, F53, G23, J61

Keywords: $\quad$ portability, acquired rights, migration, bilateral agreements, risk pooling

Corresponding author:

Robert Holzmann

E-mail: rholzmann@worldbank.org

\footnotetext{
* Revised paper prepared for the Guidance Workshop on Establishing Portability: State of the Art, Key Issues and Next Steps, Marseille Center for Mediterranean Integration, Marseille, March 10, 2010. The revision has profited from this workshop discussion, presentations at the International Organization of Migration (Geneva) and the European Center/Institute for Advance Studies (Vienna), the many valuable written comments and suggestions by Samia Kazi Aoul-Chaillou, Georg Fischer, Alvaro Forteza, Frank Hempel, Angel Melguizo, Klaus Kapuy, Marius Olivier, David Warner, a Bank internal presentation and review process, and great research support by Yann Puget. All remaining errors are our own responsibility. The paper presents the view of the authors that do not necessarily reflect the views of the organizations they are associated with.
} 


\section{Introduction}

The portability of social benefits across professions and countries is an increasing concern for individuals and policy makers. The concern reflects rising labor mobility as one feature of globalization that is visible in increasing labor movements among high income countries, an increase in population flows from the poor to rich countries, and also increasing population flows among poorer and less poor countries ${ }^{1}$. The stock of population (migrants) living outside their countries is still small (some 3\% of world population or some 200 million) and the share has been re-increasing since the 1970s (UN 2006). But the underlying flows are much higher (and less well known) as an increasing share of the population is spending some time of his or her life outside the own country' borders - mostly working but increasingly also retiring. And within countries there is noticeable increase in labor mobility across professions and sectors during the working life of individuals.

Among these labor movements it is the international migration from "South" to "North" that is getting the increasing attention by policy makers in both South and North. In the North it is the strong inflow of migrants till the economic crisis and the projected population aging and low or even negative labor force growth that heightened the interest of policy makers in migration issues, including portability of social benefits, as the perspective of returning migrants is politically more palatable. In the South, migration is increasingly seen as potential development instrument of a country: in the short term to ease labor market pressures among youth and to receive valuable remittances; in the medium to long-term to have return migrants contributing with human and financial capital to firm creation, employment and economic growth. Return migrants with portable social benefits increase their value and save domestic budgetary resources.

Whatever the motivation for the labor mobility across countries and professions, from a first-best economic point of view individual labor mobility decisions should not be influenced by the lack of portability of social benefits for which he or she has established acquired rights. $^{2}$ From a social policy point of view such acquired rights are a critical element of the individual's (or family's) life-cycle planning and social risk management. From human rights point of view individuals (nationals and migrants) have the right to social protection according to national legislation and international conventions and these rights, at least the acquired ones, carry over also when leaving the country or profession. All these motivations suggest eligibility to and disbursement of social benefits in payment should not depend on the chosen country of residency and both elements should be part of a definition of portability developed in the paper.

Over recent years the interest in empirical as well as conceptual penetration of portability issues has notably increased as visible by the rising number of papers written on the

\footnotetext{
${ }^{1}$ At times we will use a simplifying albeit imprecise abbreviation for these labor movements between rich (“North") and poor ("South") countries.

${ }^{2}$ In a second best world it is claimed by some authors that imperfect portability could be welfare improving in the presence of several market failure (see for example Becker, 1964; Lazear, 1979; and Fabel, 1994). While these arguments may have some validity for national labor markets we doubt that such a human Tobin tax through imperfect portability is relevant in case of cross border mobility as the involved other costs will remain high.
} 
topic. Within areas of economic integration such as the European Union (EU) the social security coordination has been on the table since 1958 and constitutes an interesting and informative real-life laboratory. The $50^{\text {th }}$ anniversary since Regulation 3 has given rise to various reviews among experts and academics, including of the most recent EU directive 2004/38. ${ }^{3,4}$ At international level, the International Labor Organization (ILO) has been pioneering international instruments for migrant workers since the 1930s, created 2 Conventions (Migration for Employment Convention (C.97), 1949 and Migration Workers Convention (C.143), 1975), and several conventions/ recommendations provide important guidance for the coordination of social security schemes. ${ }^{5}$ The ILO Multilateral Framework on Labor Migration endorsed by the ILO Governing Body in March 2006 details the principles and guidelines for a rights-based approach (ILO, 2009). One indicator of the effects of the ILO Conventions is the number of ratifications of each convention. As some obligations concern the commitment to conclude bilateral or other multilateral social security agreements, these conventions may have fostered a network of those bilateral or regional multilateral agreements.

Table 1: Ratification of ILO Conventions in early 2010

\begin{tabular}{|c|c|c|c|}
\hline $\begin{array}{c}\text { Convention No. (year of } \\
\text { adoption) }\end{array}$ & $\begin{array}{c}\text { Ratifications in all } \\
\text { regions }\end{array}$ & $\begin{array}{c}\text { Ratification in } \\
\text { Europe }\end{array}$ & $\begin{array}{c}\text { Ratification in other } \\
\text { regions }\end{array}$ \\
\hline Convention No.19 (1925) & 121 & 33 & 88 \\
\hline $\begin{array}{c}\text { Convention No. 102, Art. 68 } \\
\text { (1952) }\end{array}$ & 46 & 31 & 15 \\
\hline Convention No. 118 (1962) & 37 & 10 & 27 \\
\hline Convention No. 157 (1982) & 4 & 2 & 2 \\
\hline
\end{tabular}

Source: ILO (per direct communication by Frank Hempel)

These legal and human rights based considerations are increasingly (but only slowly) joined by economic considerations that help underpin the social policy objectives with a more analytical and empirical framework. Examples include Holzmann-KoettlChernetsky (2005) offering a first framework, data, and good practices on portability regimes (prepared for the Global Commission on Migration); regional work on social protection management for migrants between EU and North Africa (Koettl, 2008; KoettlMorghandi-Van der Bosch, 2009); an analysis on the portability of pension rights for the Caribbean (Forteza, 2009), and a comprehensive review analysis of social protection for migrants in North and South, and the portability linkage (Sabates-Wheeler and MacAuslan, in print). ${ }^{6}$ The economic analysis has recently also been deepened by

\footnotetext{
${ }^{3}$ See the special issue of the European Journal of Social Security 2009, Tsotsorou (2009), and Pieters and Schoukens (2009).

${ }^{4}$ The most relevant EU regulation comprises Council Regulation (EEC) No. 1408/71 of 14 June 1971 and Council Regulation (EEC) No. 574/72 of 21 March 1972 and the new regulations, which enter into force on 1 May 2010: Regulation (EC) No. 883/2004 of the European Parliament and the Council of 29 April 2004 and Regulation (EC) No. 987/2009 of the European Parliament and the Council of 16 September 2009.

${ }^{5}$ ILO Conventions No 19, 102 (Article 68), 118 and 157 and ILO Recommendation No. 167 with the model provisions in Annexes 1 and 2.

${ }^{6}$ A separate paper $<$ Portability_Literature $>$ tries to trace and take stock of the literature on the portability of social benefits and put on the web as living document, see www.euromedina.org/CMI (operating soon).
} 
modeling portability and providing empirical indications of potential importance (e.g. Jouston and Pestieau, 2002; Fenge and Weizsaecker, 2009).

All this work has led to a better understanding of the objectives of portability, the broad portability regimes, and the role of bi-lateral agreements between countries. But we are still some way off to advise policy makers in North and South what best to do to ensure portability across countries and professions and to substantiate that this matters. This is conjectured to reflect the lack of a shared conceptual understanding; very incomplete empirical knowledge of what works, what does not work and why; and lack of data, understanding of processes, etc.

In order to progress in this direction, this paper has the following structure: The next section (Section 2) provides a broad picture on portability regimes across regions and how it applies to migrant' countries in the world. Section 3 proposes to step back and undertake a conceptualization of portability starting out with the (domestic) social policy objectives of social benefits compared to the more (international) economic objectives of labor mobility and offers an analytical framework for portability analysis that suggests separating the risk pooling, (implicit or actual) pre-funding and redistributive elements in the benefit design for better portability. Section 4 applies this conceptual framework to (old-age) pensions while Section 5 provides an analysis for health care benefits. Section 5 highlights key issues that need to be address to further our understanding of portability for the benefit of better policy design while Section 6 concludes.

\section{Facts on Migration and Portability Regimes}

To grasp the importance of portability issues this section presents broad estimates of portability regimes that apply to legal and illegal migrants across the world regions. It builds on an approach developed by Holzmann-Koettl-Chernetsky (2005) for a background paper of the Global Commission for International Migration and draws on more recent estimates by Avato (2008) and Avato-Koettl-Sabates-Wheeler (2009).

The social protection status of migrants can be classified into four regimes (Holzmann et al. 2005):

Regime I (Portability) includes all legal migrants enjoying indiscriminate access to social services in their host country, and home and host country have concluded a bilateral or multilateral social security agreements to guarantee full portability of accrued benefits. Regime I is the most favorable regime in terms of formal social protection for migrants. This status can mostly be found within the EU and between many high-income countries with well-developed social security systems. These agreements, however, have varying depth with regard of benefits covered and rules applied to such benefits, with unknown statistics about coverage and rules.

Regime II (Exportability) includes all legal migrants who have access to social services and social security in their host country without a bilateral arrangement being concluded between their host and origin country. For example, migrants may receive benefits abroad, but cannot rely on totalization of their contribution periods, i.e. eligible benefits are made exportable but acquired rights are not fully portable. The extent to which benefits are payable abroad is exclusively subject to national legislation, and host and home country do not cooperate when determining and paying benefits. For example, the 
UK allows for claiming of benefits by individuals who moved abroad but does not totalize contribution periods for individuals who moved to a country where no bilateral agreement has been concluded. In addition, in such cases pensions may not be indexed, so that the pension amount is not adjusted over time (Avato 2008). ${ }^{7}$ This regime concerns the largest number of international migrants.

Regime III (Access exclusion) includes all legal migrants who do not have access to social security in their host country - either because they are excluded or because there is no social security system in their host country. Access exclusions for not permanent residents is the case for the Gulf Cooperation Council (GCC) countries in the Middle East, or Singapore. It should be noted that despite this disadvantage of access, migrants are also not required to contribute to long-term benefits like old-age pensions, thus strictly speaking, they do not lose contributions and may, in principle, contribute into a private scheme elsewhere or remain insured in the home country, if possible.

Regime IV (Informality), finally, includes all undocumented migrants who arguably face the greatest challenge regarding their social protection. They have very limited access to social services and social security and are subject to unchecked and unregulated labor market conditions. This regime particularly concerns migrants moving between lowerincome countries.

The following global estimates on the status of social protection for migrants are based on two inputs: first, data from the Development Research Centre on Migration, Globalisation, and Poverty (Migration DRC), which gives over 50,000 estimates of bilateral migrant stocks, based on the 2000/01 census round (Migrations DRC 2004); second, legal data on bilateral and multilateral social security agreements. Since undocumented migrants-Regime IV migrants—are in an especially precarious situation regarding social protection, special attention was paid to estimating the number of undocumented migrants. This required strong assumptions in countries where census data was weak and where migrants were not adequately captured by censuses. ${ }^{8}$

The estimates result in almost 187 million migrants in 2000/01 worldwide (see Appendix Table B). Eastern Europe and Central Asia (ECA) has the highest share of migrants, particularly as a consequence of the break-up of the Soviet Union. The second biggest sending region is the EU-27 and other Europe. In all regions-except in Latin America and Caribbean (LAC) - intra-regional migrants constitute the highest share of all migrants. North America, followed by the EU-27 and other Europe, are the biggest receiving regions. ${ }^{9}$ Low and lower middle-income countries are the biggest migrant senders, supplying about 70 percent of the world's migrant stock. High-income countries, which host 50 percent of all migrants, only send 19 percent of migrants. Thus, southnorth and south-south migration flows are largest (see Appendix Table A).

\footnotetext{
${ }^{7}$ In an interesting recent Judgment, the European Court for Human Rights (ECtHR) found with respect to the indexation of retirement pensions no discrimination between pensioners living in a country with which the UK has no bilateral social security and pensioners living in a country which is covered by an agreement; see ECtHR (2010).

${ }^{8}$ See Avato et al. (2009): 19 for details.

${ }^{9}$ For regional and income country grouping, see World Bank (2009).
} 
This stands in contrast to the social protection status of migrants where mostly northern migrants are protected. About 23 percent of global migrants fall under the favorable Regime I of full access and full portability, mostly originating from the EU-27. Overall, most migrants under Regime I move between high-income countries (see Table 2). In fact, the share of migrants under Regime I increases with the income level of the origin country. Even though some low and lower-middle income countries are able to protect their emigrants by social security agreements, the largest sending countries such as Russia, Mexico, India, Bangladesh, Ukraine, and China-with emigrant stocks between 6 and 13 million-had until recently concluded next to no bilateral portability arrangements but changes are under way. Moreover, the multilateral agreements in South and Central America, MERCOSUR and CARICOM, cover merely 27 percent and 2 percent of their emigrants by the respective agreements (Avato et al. 2009) and implementation has not been rated as very effective (Forteza 2008). Thus, protecting emigrants through bilateral agreements seems to be a practice that is primarily common in high-income countries.

Table 2 Global emigrant stock estimates by origin country income-group and Portability Regime (2000)

\begin{tabular}{|c|c|c|c|c|c|c|}
\hline $\begin{array}{l}\text { Origin country } \\
\text { income-group }\end{array}$ & $\begin{array}{r}\text { Regime I } \\
\text { (Agreement) } \\
\end{array}$ & $\begin{array}{l}\text { Regime II } \\
\text { (National) } \\
\end{array}$ & $\begin{array}{r}\text { Regime III } \\
\text { (No Access) } \\
\end{array}$ & $\begin{array}{l}\text { Regime IV } \\
\text { (Informal) } \\
\end{array}$ & Total & $\begin{array}{r}\% \\
\text { global } \\
\text { stock } \\
\end{array}$ \\
\hline $\begin{array}{l}\text { Low-income } \\
\text { countries }\end{array}$ & 850,985 & $36,720,832$ & $5,293,338$ & $10,757,086$ & $53,622,241$ & $29 \%$ \\
\hline$\%$ total & $2 \%$ & $68 \%$ & $10 \%$ & $20 \%$ & $100 \%$ & \\
\hline $\begin{array}{l}\text { Lower middle- } \\
\text { income } \\
\text { countries }\end{array}$ & $11,312,511$ & $47,224,671$ & $3,476,163$ & $14,473,805$ & $76,487,150$ & $41 \%$ \\
\hline$\%$ total & $15 \%$ & $62 \%$ & $5 \%$ & $19 \%$ & $100 \%$ & \\
\hline $\begin{array}{l}\text { Upper middle- } \\
\text { income } \\
\text { countries }\end{array}$ & $3,521,212$ & $10,724,671$ & 189,357 & $7,203,975$ & $21,639,215$ & $12 \%$ \\
\hline$\%$ total & $16 \%$ & $50 \%$ & $1 \%$ & $33 \%$ & $100 \%$ & \\
\hline $\begin{array}{l}\text { Non-OECD } \\
\text { high-income } \\
\text { countries }\end{array}$ & $2,063,914$ & $3,534,415$ & 192,987 & 57,809 & $5,849,125$ & $3 \%$ \\
\hline$\%$ total & $35 \%$ & $60 \%$ & $3 \%$ & $1 \%$ & $100 \%$ & \\
\hline $\begin{array}{l}\text { OECD high- } \\
\text { income } \\
\text { countries }\end{array}$ & $24,778,310$ & $3,658,850$ & 291,007 & 189,802 & 28,917,969 & $16 \%$ \\
\hline$\%$ total & $86 \%$ & $13 \%$ & $1 \%$ & $1 \%$ & $100 \%$ & \\
\hline Total & $42,526,932$ & $101,863,439$ & $9,442,852$ & $32,682,476$ & $186,515,699$ & $100 \%$ \\
\hline \% global stock & $23 \%$ & $55 \%$ & $5 \%$ & $18 \%$ & $100 \%$ & \\
\hline
\end{tabular}


The main problem of poorer countries seems to be less developed social security system and, more general, less developed social protection frameworks for their residentsnationals and migrants alike. The size of their informal labor market is large so that many workers are not covered by formal social protection. Immigration policy is often more geared towards restricting and controlling migration rather than securing the statues of migrants. These factors reduce their ability to negotiate and administer social security agreements. $^{10}$

Moreover, undocumented migration is much higher in poorer countries as can be seen in Table 3. While many informal migrants may live in high-income countries, very few originate from these countries and many remain in their (poorer) region. These migrants have next to no place to claim any sort of formal social protection and rely on informal social protection networks. In fact, many migrants see migration itself as a strategy to escape poverty in their home country, and thus, in a way, benefit from migration without any sort of formal social protection (Sabates-Wheeler 2008).

Table 3: Global migrant stock estimates of Regime IV migrants only (undocumented migrants) by origin and host income-group (2000)

\begin{tabular}{|c|c|c|c|c|c|c|}
\hline \multirow[b]{2}{*}{$\begin{array}{l}\text { Origin country } \\
\text { income-group }\end{array}$} & \multirow[b]{2}{*}{$\begin{array}{r}\text { Low-income } \\
\text { countries } \\
\end{array}$} & \multicolumn{4}{|c|}{ Host country income-group } & \multirow[b]{2}{*}{ Total } \\
\hline & & $\begin{array}{r}\text { Lower middle- } \\
\text { income } \\
\text { countries } \\
\end{array}$ & $\begin{array}{r}\text { Upper middle- } \\
\text { income } \\
\text { countries }\end{array}$ & $\begin{array}{r}\text { Non-OECD } \\
\text { high-income } \\
\text { countries } \\
\end{array}$ & $\begin{array}{r}\text { OECD high- } \\
\text { income } \\
\text { countries } \\
\end{array}$ & \\
\hline $\begin{array}{l}\text { Low-income } \\
\text { countries }\end{array}$ & $3,775,249$ & $3,681,516$ & 781,597 & 561,591 & $1,957,132$ & $10,757,086$ \\
\hline $\begin{array}{l}\text { Lower middle- } \\
\text { income } \\
\text { countries }\end{array}$ & 779,250 & $6,156,610$ & $1,471,782$ & 970,669 & $5,095,494$ & $14,473,805$ \\
\hline $\begin{array}{l}\text { Upper middle- } \\
\text { income } \\
\text { countries }\end{array}$ & 111,890 & 531,205 & 234,206 & 288,799 & $6,037,875$ & 7,203,975 \\
\hline $\begin{array}{l}\text { Non-OECD } \\
\text { high-income } \\
\text { countries }\end{array}$ & 1,949 & 12,663 & 3,319 & 2,052 & 37,825 & 57,809 \\
\hline $\begin{array}{l}\text { OECD high- } \\
\text { income } \\
\text { countries } \\
\end{array}$ & 11,442 & 26,805 & 17,160 & 8,563 & 125,833 & 189,802 \\
\hline Total & $4,679,780$ & $10,408,798$ & $2,508,064$ & $1,831,674$ & $13,254,160$ & $32,682,476$ \\
\hline
\end{tabular}

Note: Country income-grouping according to World Bank terminology. See World Bank (2009).

Source: Avato, Koettl and Sabates-Wheeler (2009).

From the available evidence in countries with different income levels it emerges that the practice of social security agreements is not readily transferable to poorer countries with less developed and often differing frameworks of social protection. Thus, different approaches are needed in order to bring forward improvement in social protection and portability frameworks. Improvements in coverage and portability may emerge from voluntary but government-supported programs for pension and health that are currently

\footnotetext{
${ }^{10}$ See Olivier (2009) for a detailed assessment of migrant's social protection status in the Southern African Development Community (SADC).
} 
piloted in a number of low and middle countries (see Holzmann-Robalino-Takayama, 2009). In essence the government matches voluntary contributions by individuals to pension and health care schemes that are established at local level (e.g. Matching Defined Contribution (MDC) schemes as currently under implementation in China and India) or makes the access by the elderly to such services conditional on needs and behavior of the family (Conditional Cash Transfers (CCT) programs as piloted for the elderly in Mexico).

\section{A Conceptual Framework of Portability to Assess and Improve Policy Design}

Portability issues of social benefits for internationally mobile workers (migrants) emerge from the tension between the more domestically oriented social policy objectives linked to traditional social risks and the more internationally oriented economic policy objectives linked to cross-border labor mobility; they reflect more broadly the diverging interests of host country, home country, and migrants on the topic. ${ }^{11}$ This calls for a review of objectives and instruments in both areas in order to better understand possible trade-offs as well as of the key policy options to address conflicting objectives. The proposed portability framework builds on the Social Risk Management (SRM) framework that has proven helpful in guiding social policy analysis in both developing and developed countries.

This section outlines the key elements of a conceptual framework for portability that will be applied in two following sections to pension and health care benefits. It is developed along the following topics: (i) migration and social risk management; (ii) domestic objectives and instrument design of social protection; (iii) labor mobility objectives and results criteria for portability; (iv) an analytical model for portability consideration; (v) defining portability: scope and issues; and (vi) establishing portability: policy options and issues.

\section{(i) Migration and Social Risk Management (SRM)}

Migration is quite likely the oldest, most widespread and most important risk management instrument of mankind: To address risks pro-actively (e.g. migration in response to climatic change); to mitigate risks ex-ante (e.g. migration in response to expected unemployment or diversification of risks within the extended family); and to cope with risks once they are realized (e.g. migration in response to natural catastrophes or armed conflicts). The SRM framework proposes three risk management strategies (risk prevention, risk mitigation, and risk coping) and three broad types of risk management arrangements (informal, market-based and public) to address risks. Conceptualized as social risk management it defines "Social Protection as public interventions to (i) assist individuals, households, and communities better manage risk, and (ii) provide support to the critically poor.” (Holzmann and Jorgenson, 2001).

While the emergence of formal social protection instruments (market-based and public) has reduced the importance of migration as an informal risk management instrument in

\footnotetext{
${ }^{11}$ From a politically economy point of view the tensions reflect also the interest of the mobile compared to the immobile labor force within and between countries.
} 
the developed world, it remains a crucial informal and formal risk management instrument for the developing world. And both formal and informal instruments are closely intertwined:

- With migration from South to North individuals attempt to address specific risks (poverty, unemployment, diversification needs) but get exposed to new risks and loose access to prior risk management instruments (certainly informal such as family and possibly formal such as social insurance and assistance). Hence access to social protection and portability of social benefits becomes crucial for migrants to address risks in host and home country.

- Labor migration has a critical impact on the formal and market-based SRM instruments in both home and host country. For the (youthful) home countries labor migration reduces the unemployment pressure for youth and the remittance have proven important instruments to address idiosyncratic and systemic risks (such as macroeconomic shocks). For the (aging) host countries labor migration supports the formal risk management instruments (in particular pensions and health programs) by increasing labor force and hence the internal rate of return of such programs as well as skill profile and supply of health workers.

- Access to and portability of formal SRM instruments for migrants is likely to change the size as well as composition of migrant flows to the host countries as they have a major bearing on the key choices and decisions by labor migrants (Koettl-MorgandiVan der Bosch, 2009). This makes access and portability regimes for social benefit a critical instrument of migration management (Holzmann and Pouget, 2010a).

- For migrants portability (of acquired rights) is the interface between the social services in home and host countries (see Figure 1). Such services include health care benefits, long-term social security benefits like old-age and disability benefits, and short-term benefits like social assistance, maternity, and unemployment benefits, family allowances as well as public housing and education.

\section{Figure 1: Social Services for Migrants}

$\begin{array}{lll}\text { Sending/home country } & & \text { Receiving/host country } \\ \text { - Social services for } & \text { - Portability of } & \text { - Social services for } \\ \text { remaining family } & \begin{array}{l}\text { acquired social } \\ \text { rights between }\end{array} & \text { migrants and their } \\ \text { members } & \text { receiving and } & \text { families } \\ \text { - Social services for } & \text { sending country } & \text { - Labor market } \\ \text { returning migrants } & \text { conditions for migrants. }\end{array}$

Source: Based on Koettl (2006)

\section{(ii) Domestic Objectives and Instrument Design of Social Protection}

Formal social protection instruments to mitigate or cope with risks have been developed in the now rich countries in the North over more than 100 years followed by a gradual diffusion to most countries in the world. Social insurance programs that link benefits to prior contributions typically started out with a narrow focus on sectors (trades) and coverage moved from civil servants to white and then blue collar workers, to farmers and 
self-employed, and to voluntarily insured. The original benefit design was geared toward specific sector interests with little considerations for mobile workers. While some consolidating has been taking, portability of acquired rights across sectors (in particular between public and private) remains often an issue. Reform of these programs has typically proven difficult as reform resistance was driven by the narrow interests of the sector members (and the dominance of the many immobile compared to the few mobile members). Portability considerations in design and implementation entered only slowly with the rise of labor mobility across professions and countries (and in the EU with the strife to establish the freedom of labor movement and with the ILO's Conventions and advocacy work to protect migrant workers and expand coverage ${ }^{12}$ ). But domestic considerations are still given dominance in the social protection area (unless they contradict EU objectives or ratified ILO Conventions). The situation is similar, or worse, in countries where benefit eligibility are linked to residency (and notional contributions to general tax revenues over the life cycle). Portability of such benefits is at first sight an alien concept.

These origins and the historical sector focus are still very much visible in the benefit design of social insurance programs, which typically cover the risk mitigation instruments for old-age, disability, survivorship, unemployment, sick-pay and maternity, work injury and professional diseases, family benefits, and health care benefits. Most visible are the domestic objectives in the design of pension benefits where long vesting periods, last salary assessment features and non-linear accrual rates reflect very much historic schemes geared toward immobile civil servants. While civil servants initially did not pay contributions they were introduced for the financing of private sector schemes but much of the non-actuarial benefit structure was often left unchanged. And it is these features that render benefit portability across schemes (of sectors and countries) difficult. A more similar and actuarial structure would facilitate the portability of benefits across professions and borders. While portability considerations may not be strong enough to encourage domestic benefit reforms toward a more transparent and actuarial structure, labor market considerations and population aging are motivating many reforms in this direction.

\section{(iii) Labor Mobility Objectives and Results Criteria for Portability}

There are a variety of objectives that can be raised to support the demand for full portability of social benefits. At the end they boil down to two: fairness and efficiency considerations.

Fairness considerations can be raised at individual and country level. At individual level it can be claimed that full portability should be established as a matter of fairness. If an individual has contributed (mandatorily or voluntarily) to programs to mitigate future risks to allow him or her consumption smoothing across the states of the world, then acquired rights should become portable across time and space. Similar considerations

\footnotetext{
${ }^{12}$ Work by the ILO include a project on "Strategies for extending social security to African migrant workers and their families; 2008-2011". The strategic approach is to promote different mechanisms or policy options in order to enhance migrant's workers social security coverage (ratification of ILO Conventions on social security coordination, bilateral and multilateral social security agreements, unilateral measures, and community-based initiatives).
} 
apply at country level. If an individual moves between countries, denying portability of acquired rights provides a windfall profit for the country the mobile work leaves while potentially burdening the new country of residency.

Efficiency considerations of portability are closely link with the labor market, but go beyond. Full portability should render the labor mobility, labor supply, and residency decision neutral to social benefit aspects. In the absence of full portability individuals (and families) may decide not to (temporarily or permanently) migrate or return, or decide to offer labor in the informal sector with possible stark implication for overall tax revenues and economic growth of a country.

To assess the mobility bias in and between national pension systems specific assessment criteria have been proposed (Fenge and Weitzsaecker, 2009). For national pension schemes the authors propose a "Lodge test"13 to asses if the benefit formula inherently discriminates between mobile and immobile workers. For mobility distortions that may arise as the difference between nation schemes they propose the implicit tax rates (on pension contributions as an investment) and differences can be due to different implicit rates of return and tax treatment. While the latter is interesting, it goes beyond the typical and operational policy concerns.

To address mobility concerns and in order to assess if the portability arrangements succeed in delivering on the fairness and efficiency considerations, three broad results criteria (for pension and health care benefits) have been suggested (Holzmann-KoettlChernetsky, 2005):

Criteria 1: No benefit disadvantage with regard to pension and health care for migrants and their dependents. Movements between host countries or back to source country should not lead to lower pension benefits or gaps in health coverage compared to staying in one country.

Criteria 2: $\quad$ Fiscal fairness for host and source countries. No financial burden should arise for the social security institution of one country while the social security institutions of the other country benefit from any provisions on portability or the lack thereof.

Criteria 3: Bureaucratic effectiveness. The administrative provisions on portability or the lack thereof should not cause a bureaucratic burden for the institutions involved and should be easily to handle for migrants.

\section{(iv) An Analytical Model for Portability Considerations}

The prior two sub-sections have motivated the importance of a more actuarial structure of social benefits to achieve labor mobility while being able to carter toward domestic policy objectives. This sub-sections provides an analytical framework how best to achieve this while keeping critical features of publicly mandated social insurance benefits, such as redistribution. It starts out with a motivation of the approach and application to current social benefits. And it ends with a simple analytical model in

\footnotetext{
13 The test is name "Lodge Test" in honor of David Lodge, the author of a novel "Changing Places" that offers a humorous account of an international swap of two academics.
} 
general notation that is made more concrete when applied to pension and health care benefits in the following sections.

\section{The insurance, saving and distributive components of social insurance benefits: A motivation}

In a nutshell, critical for portability considerations of all risk mitigation instruments is the disentangling of (i) the social insurance component; (ii) the (implicit or explicit) savings component; and (iii) the redistributive component of social benefits. Essentially all social benefits contain (explicit but mostly implicit) elements of insurance as risk pooling against a specific (group of) risk(s), "pre-saving” or at times savings-credit/tax mechanism across the individual life-cycle, and explicit or implicit redistribution within and between cohorts (Holzmann, 1990). Social insurance (with risk pooling across different risk profiles) and explicit redistribution constitute the key elements of 'solidarity" albeit this notion is hardly ever defined in such analytical terms. The presaving element exists also in unfunded or Pay-As-You-Go schemes although it is typically not conceptualized or recognized as such. These distinctions matters less for portability of benefits in disbursement but is crucial for portability of acquired rights before eligibility and this is different across benefit types:

Old-age pension benefits: This is the (relatively) easiest benefit for such a distinction as it separates clearly between saving (pre-funding) and risk coverage. Saving (accumulation) happens before retirement (as actual savings in funded schemes or implicit pre-funding in nonfinancial (or pay-as-you-go) DC and DB schemes; for the latter they can also be conceptualized as the value of accrued-to-date liability). At retirement such accumulations are transformed into an annuity to insure against the uncertainty of death. Accumulations (acquired rights) before retirement should be, in principle, straightforward to be made portable. Once the benefit is in disbursement the individual is member of the risk pool and there are few economic and social policy reasons why the receipt of the pension should be made dependent on the lieu of residency. However, acquired rights and pensions contain sometimes also important elements of redistribution at the level of contribution collection and benefit formula that make portability less straightforward. Explicit and implicit redistribution happens at the time of accumulation (through contribution and benefit formula) and at disbursement (through pooling of different survival profiles); this can be conceptualized as deviation of a quasi-actuarial contribution-benefit link and measured via differences in the internal rate of return.

All other social (cash) benefits insure also against a specific risk, have mostly elements of some (implicit) pre-saving but also elements of redistribution in contribution and/or benefit design. And financing is in some cases done by general taxes and not earmarked contributions. In addition, the insurer (government or private sector) wants to be able to assess the state of the world and stop paying when the risk ceases to exist, which is more difficult when payments happen to abroad. All this renders decisions about scope and limits of portability quite complex. A few first (and incomplete) considerations:

Sick pay: The payment is linked to a short-term risk but with payouts typically increasing with age and proportionate to wages. This implies some pre-saving but limited redistributive features in a wage-based contributory scheme. Hence little issues 
of transfer of acquired rights should emerge when changing the country (or employer) while benefits in disbursement could, in principle, be paid under existing rules. But the verification of pre-existing conditions or continued sickness may prove difficult in most cases and hence portability has typically not been established (or proposed). Issues of acquired rights, however, emerge if sickness leads to work related work injury claims or non-work related disability claims after changing employer or residency. They ought to be addressed through work injury and disability benefits that contain, as old-age pensions, a major pre-saving element. And benefits include also major non-cash benefits for rehabilitation and labor market re-integration.

Unemployment benefits: The benefit payment is linked to a short-term risk and has some pre-saving elements if older workers are more prone to unemployment as well as redistributive features if the unemployment risk is not equally distributed across individuals (professions). A pre-saving element begs the question for a transfer of acquired rights (pre-saving element) that has not yet been raised and would in most schemes be difficult to establish given also the strong redistributive features of typical unemployment insurance schemes (through pooling of high and low unemployment risks, and distributive features in benefits favoring often the lower income groups). But the issue of payment of unemployment benefits when moving abroad to find a job has been raised within the EU. This begs also the question of risk control (is the beneficiary still unemployed and looking for a job) for the sending country as well as the access to unemployment services (including training) in the receiving country.

Family benefits: Typical benefits in European and other countries include child care benefits to alleviate the financial burden of raising children that are, at times, financed through contributions (by employers and/or employees); but the logic holds also when general tax financing is applied. The objective is largely redistributive (towards children and families with low income). Conceptually it has a pre-saving-credit/tax element as contributions (saving) when young (and childless) and contributions (repayment) when old (and children are out of the house) help finance the expenditure and constitute an instrument of inter-temporal and intra-personal income redistribution. Hence continued payment of benefits when moving abroad would be consistent with the logic (and is done by some countries for nationals and in very limited cases for nonnationals). But the pre-saving-credit/tax structure invites also for welfare arbitrage and possible fiscal unfairness may call for restrictions/re-reimbursement.

Health care benefits: Health care benefits contain a major element of redistribution and pre-funding in both public and private scheme. Contributions are typically flat or a fixed share of income, while health care expenditures are rising strongly with age. This allows for the (implicit) accumulation of funds when younger from which excess expenditures at higher age are paid. This should allow for the portability of health-care benefits when retired but also the transfer of the accumulated funds while active and changing countries. Critical issues concern the calculation of the transferable funds in view of different risk profiles (and incentives for the receiving country' institution), differences in health care costs between sending and receiving country, and the redistributive contribution feature in many countries (i.e. charging earnings-related but not flat rate contributions; redistribution from single households to families; tax-financing of health expenditures). 
It should have become clear by now that the specific program objectives and design features have a bearing on portability. Some benefit designs are much more amendable to portability than others. If portability is considered very critical to address fairness and efficiency concerns across space, professions and time this may call for changes in program design which may create a trade-off between different social policy and economic objectives. Well-known examples are defined benefit versus defined contribution (DB, DC) schemes in pension and unemployment benefit programs. Furthermore, for key social programs there is a trend to multi-pillar arrangements consisting of basic (and tax financed), mandated (and contribution based) and voluntary (and premium-based) provisions (such as in old-age and health care benefits). For fairness and efficiency considerations of portability, all pillars need to be considered.

The insurance, saving and distributive components of social insurance benefits: A simple analytical model

In a world of homogenous individuals exhibiting the same risk profile and under full information individuals would be able in every period to insure themselves against wellspecified risks with a fair insurance premium. And portability would not be an issue when changing the country; they would simply buy an actuarially fair insurance for each period in the new host country.

The insurance component of a one-period benefit with homogenous individuals, without pre-saving and redistribution has a simple budget constraint:

\section{[3.1] $\quad \mathrm{c}(\mathrm{a})=\mathrm{b}(\mathrm{a}) \mathrm{p}(\mathrm{a})=\mathrm{E}[\mathrm{b}(\mathrm{a})]$}

with $\mathrm{c}(\mathrm{a})$ the contribution/insurance premium at age $a, b(a)$ the benefit paid in case of risk realization, $p(a)$ the probability of the risk, and $E[b(a)]$ the expected benefit. The insurance is fair and aggregated across (homogenous) individuals assures budget balance.

If the risk and/or price of the benefit package increases with age, individuals would simply pre-save for future higher contribution payments. But this can also be addressed by levying a contribution above period insurance costs at younger ages thus building a pre-saving component into the insurance package. In this case the contribution at young age pays for a period insurance component plus a period pre-saving component for future insurance coverage.

If (actual or notional) pre-saving is introduced, the period budget constraint is extended to

$$
\mathrm{c}(\mathrm{a})-\mathrm{E}[\mathrm{b}(\mathrm{a})]=\mathrm{s}(\mathrm{a})
$$

with s(a) the period pre-savings available at end of period a.

In the case of changing the country the individual has now accumulated pre-savings that he needs to take along to establish portability.

Accumulating the individual savings till an (arbitrary migration) age ã and using capital letters for the aggregated amount at this age (measured at end-period) gives

$$
S(\tilde{\mathrm{a}})=\sum_{a=1}^{\tilde{\mathrm{a}}} s(a)(1+r)^{\tilde{\mathrm{a}}-a}=\sum_{a=1}^{\tilde{\mathrm{a}}}[c(a)-\mathrm{E}[(a)]](1+r)^{\tilde{\mathrm{a}}-a}=C(\tilde{\mathrm{a}})-B(\tilde{\mathrm{a}})
$$


with $r$ the (actual or notional) rate of return provided by the system and consistent with the macroeconomic budget balance. $C(\tilde{a})$ are the aggregated contributions paid into the system plus the returns received; $B(\tilde{a})$ is the aggregated (present) value of the insurance component and is independent whether any benefits had been received.

At the date of migration (which is the beginning of period a +1 ) the present value of the (expected) future benefits $\mathrm{B}^{\mathrm{e}}(\tilde{\mathrm{a}}+1)$ minus the present value of any (expected) future contributions $C^{\mathrm{e}}(\tilde{a}+1)$ till the latest possible age of death $\mathrm{a}^{\mathrm{d}}$ in the new host country is:

[3.4] $B^{e}(\tilde{\mathrm{a}}+1)-\mathrm{C}^{\mathrm{e}}(\tilde{\mathrm{a}}+1)=\sum_{a=\tilde{\mathrm{a}}+1}^{\mathrm{a}^{\mathrm{d}}} \frac{b(a) p(a)}{(1+r)^{\mathrm{a}-\tilde{\mathrm{a}}+1}} \sigma(\tilde{\mathrm{a}}+1, a)-\sum_{a=\tilde{\mathrm{a}}+1}^{\mathrm{a}^{\mathrm{d}}} \frac{c(a)}{(1+r)^{\mathrm{a}-\tilde{\mathrm{a}}+1}} \sigma(\tilde{\mathrm{a}}+1, a)$

The present value of the future benefits depends on the survival probability from migration age to age a $-\sigma(\tilde{a}+1, a)$, the benefit level $b(a)$, and the probability (risk) of using the benefit $\mathrm{p}(\mathrm{a})$. The latter is typically 1 for pension benefits but below one and rising with age for health care benefits.

If the (new) host country has the similar characteristics as the (old) host country the expected present value of benefits minus contributions is positive and needs to be financed with external financing. If the characteristics in both countries are identical the accumulated and portable savings provide this financing match:

[3.5] $C(\tilde{\mathrm{a}})-\mathrm{B}(\tilde{\mathrm{a}})=B^{e}(\tilde{\mathrm{a}}+1)-\mathrm{C}^{\mathrm{e}}(\tilde{\mathrm{a}}+1)$

Equation [3.5] presents the actuarially fair scheme in which the expected value of future benefits minus future contributions equals the level of savings, or what is left, at each age. If this is not the case, redistribution is taking place in the form of (implicit or explicit) taxation or transfer. Introducing $R(\tilde{a})$ as the present value of the redistribution component at age ã in equation [3.6] completes the exercise; and $R(\tilde{a})$ can be positive or negative depending if it is an transfer or a tax.

[B.6] $S(\tilde{\mathrm{a}})+R(\tilde{\mathrm{a}})=C(\tilde{\mathrm{a}})-\mathrm{B}(\tilde{\mathrm{a}})+R(\tilde{\mathrm{a}})=B^{e}(\tilde{\mathrm{a}}+1)-\mathrm{C}^{\mathrm{e}}(\tilde{\mathrm{a}}+1)$

The left hand side signals the amount of resources that is at stake when moving across sectors or borders. There should be little arguments that the savings component should become portable (at accumulation and disbursement stage). There may be some discussion about the portability of the redistributive component, in particular if it is negative. If no (implicit or notional) savings or distributive component exists, the question of portability should not emerge. These issues are discussed when applying the model to pensions and health care benefits later in the paper.

\section{Defining Portability: Scope and Issues}

A first decision about portability concerns to what social risk management instruments portability should apply. Those based on mandated (public program) contributions and occupational or voluntary (private sector program) premiums (i.e. "acquired rights”) or also those based on needs-based considerations that are tax-financed? The legislation and ruling within the European Union and the Conventions by the ILO restrict portability on benefits based on acquired rights, albeit not necessarily contribution financed but based on prior length of residency (and general tax payment). 
This suggests a definition of portability (albeit still vague) that defines it as the ability to preserve, maintain and transfer vested social security rights or rights in the process of being vested, independent of profession, nationality and country of residency. Hence portability consists of two critical elements:

- The full receipt of vested and eligible social security rights as well as rights under private sector arrangements (benefits in disbursement, health care coverage) based on acquired rights through prior contributions/premiums or residency criteria in any chosen residency

- The full transfer of social security rights as well as rights under private sector arrangements that are in the process of being vested before eligibility has been established based on acquired rights through prior contributions/premiums or residency criteria in any chosen residency

This definition raises many questions for many of which good answers are not yet available, starting-out what constitutes acquired rights, and possible limits; how should they be calculated and financed if transferred?; how does this apply to residency-based and tax financed benefits?; will solidarity be a victim of portability?; etc. Examples include:

- Are the acquired rights limited to the actuarial value of own contributions (such as in pensions) or do they extend to the present value of expected benefits based on prior contributions (accrued-to date liability) that may contain major distributive elements across and within cohorts or may not be financially sustainable? Should all, some, or none of the redistributive component be acquired rights be recognized? The question emerges as property rights are typically not well defined in social insurance programs. In a Coasian world of well defined property rights issues of portability would not emerge.

- How should such the acquired rights and hence transfer amount be calculated backward-looking based on passed contributions and risk profile under the old institution or forward-looking based on expected net-benefits (i.e. present value of benefits minus remaining contributions) under the new institution. As outline above, in actuarially fair and balanced systems and equal settings both should be equivalent. However in non-actuarial system that is furthermore fiscally unbalanced such a forward-looking calculation creates distortionary incentives and a transfer that makes at least one institution (sending or receiving) worse off.

- How should the transfer amount be financed in pay-as-you-go schemes? While only the net amount (of inflows and outflows) needs to be financed they could still exceed the available reserves in more traditional pensions and health care schemes. In NDC-type schemes there is in any case the need for a reserve fund to address shocks that could be used(see, Holzmann, Palmer and Robalino, 2011). Alternatively, and in a world of perfect access to the capital market, the netsending social insurance institution (or government) could issue GDP bonds that would be transferred to the receiving country. ${ }^{14}$

\footnotetext{
${ }^{14}$ For the concept of GDP bonds as collateral for PAYG asset in DC-type pension schemes, see PrietoValdez (2005) and Robalino-Bodor (2009).
} 
- As voluntary premiums to private sector programs (in particular supplementary old-age pensions and health care) are part of SRM and increasing in importance world-wide they should also be made portable for the same fairness and efficiency reasons. If they are employers sponsored they may contain main elements of enterprise-specific human resource policy and hence imply rational restrictions to portability; how should this be addressed? And such programs are often taxprivileged. How would an efficient and fair tax treatment for individuals, enterprises, sending and receiving country look like?

- What happens in the case of residency-based benefits (such as demogrants) that are tax financed? Portability of such residency-based and typically flat-rate benefits can be conceptualized by the tax contribution of individuals throughout their working life. Should they be included on a pro-rata residency basis?

- Benefits in disbursement (such as pensions) often contain elements of social assistance and other top-ups (e.g. for housing, etc). Should they be also portable, to what extent, or restricted to the country of residency? Does indexation apply to these benefits or is it restricted to the country of disbursement?

Many of these questions touch on issues of "solidarity" and have raised concerns that this important pillar of the welfare state may fall victim to attempts of establishing portability. This needs not to be so and to this end will require both appropriate benefit design as well as international coordination. Portability does not change the risk pooling element of solidarity as individuals will stay in the same risk pool (e.g. for benefits in disbursement) or move from one risk pool to another (e.g. if acquired rights are transferred). For the redistributive part of programs, this requires best international agreements and reciprocity. For example, what redistributive elements in social insurance scheme can be taken along with the transfer of acquired rights from the sending country, and what social assistance elements are provided by the receiving country? And to this end regional agreements may be a promising way to proceed before a global extension through international conventions takes place. This is an issue under current DB-type benefit design and does not go away with a more DC-type structure. However, under the latter redistributive elements are more transparent and require typically explicit transfers from general government resources.

A further question concerns the scope of social benefits for which portability should apply. In many countries there is a realm of social benefits that could potentially qualify for portability based on acquired rights. Typically old-age pension and health care benefits get most of the attention in the portability discussion but the list is much longer (and not yet complete):

- Old age benefits

- Disability benefits

- Survivors benefits

- Workers accident and occupational diseases (invalidity benefits)

- Sick pay and maternity benefits

- Severance pay

- Unemployment benefits 
- Family benefits (such as children/family allowance)

- Health care benefits

- Long-term care benefits for the elderly

- Income replacement benefits for the care of children, sick or old people

While fairness considerations speak in favor of making all of them as portable as possible (across borders), in order to avoid biases only a few benefits may be relevant for individual mobility decisions. Furthermore, the administrative arrangements to establish and monitor portability (to avoid misuse) may prove to be very costly if they can be made to work at all (e.g. for unemployment and family benefits). They may work in a regional arrangement (such as the EU) but not across continents. From an insurance point of view, should the arrangements cover the full risk, including that of moving, or only partly insure in order to handle misuse (moral hazards)?

\section{(iv) Establishing Portability: Policy Options and Issues}

It is proposed that there are essentially two key options to establish portability of social benefits (across professions, space and time). The first one consists in changing the design of benefits to make them as portable as possible. The second one consists in a range of portability arrangements at unilateral, bi-lateral and multilateral level. Both broad options are partly substitutive, partly complementary.

\section{Changing benefit design}

The key feature of this proposal is to move toward a benefit design that distinguishes explicitly between the period insurance element and the pre-funding element of social benefits in addition to making any redistributive action outside the benefit schemes, or at least fully explicit and transparent. While this may have limited bearing on the portability of benefits in disbursement, the feature of having a clearly identified prefunding element should substantially ease portability. This is definitely the case for all social insurance type benefits, except, perhaps, family benefits. For cash benefits this suggests the (partial or full) move from a defined benefit (DB) to a defined contribution (DC) type structure. There are two aspects that allow easier portability of DC than DB benefits:

- First, accrued rights seem better defined under defined contributions (DC) than under defined benefit (DB) schemes (which as quite some irony). Under a DC scheme you get out what you paid in (plus interests) and this at the level of disbursement as well as when you migrate.

- Second, at least in funded DC schemes the accrued rights are backed by financial assets that are, in principle, fully mobile. Such mobility can also be established in non-financial (notional) DC schemes as countries need only to transfer (clear) the net value of all bi-lateral movements. If established at multilateral (regional) level any net amount would even further decease to be financed out of the reserve (buffer) fund or else debt instruments to be transferred with (netted) benefits.

Here is a brief outline for the key benefits that will be deepened for old-age and health care benefits in the next sections: 
- Old-age benefits: Moving from DB to DC scheme (funded or notional) has no material impact on portability for benefits in payment but allows an easy portability for benefits in accumulation. The amount of the latter is easily established by the individual account value and can be carried with any move between countries (or left in country if further remunerated). It requires essentially no vesting period and hence totalization, and benefits can be fully aggregated.

- Disability benefits: A move to DC plans allows governments also to rethink the design of disability benefits and to separate from old-age benefits. As the risk can be independently priced it can be established as an own scheme to finance benefits when disabled but also to contribute to the old-age DC scheme. While young the disability risk is low but length of paying toward the old-age scheme (to be financed by the disability insurance) is high; the reverse holds for older workers. This should allow keeping contributions pretty much flat and hence should create limited prefunding.

- Survivor's benefits: Moving to a DC scheme allows also the establishment of independent rights for the survivor before the death and hence full portability (and a much easier handling of divorces through the splitting of accumulated funds during marriage). Survivors benefits can then be restricted to a short-term DB scheme with the eligibility length depending on the age of children.

- Sick-pay: As sick-pay has pre-funding features there are approaches to strengthen the design with the accumulation of permissible sick-days per year (say, 2 weeks) on which individuals can draw for longer sickness while having part of their unconsumed sick-days compensated when changing employment. The latter could be made transferable to the new employer (and country).

- Unemployment benefits: Moving from DB type unemployment insurance to a DC type unemployment savings account (UISA) makes the accumulation easily transferable (also into retirement) and has conjectured positive labor market effects (Hartely et al. 2010). Of course, DB type benefits for individuals with high unemployment risks will need to be established ("social pooling"). And if borrowing from the UISA is possible there need to be a mechanism to recover these funds (say, from the retirement account).

- Health care benefits: Here one could also envisage a DC type structure that separates the prefunding from the period insurance element but the actual implementation is quite likely to be more complicated (see Section 5).

There is clearly a major trade-off between staying with an existing benefit design to carter toward domestic social benefit objectives and a benefit re-design to enhance or establish full portability. But such a trade-off may not be large as independently of portability considerations countries are moving their schemes already toward a more (actuarial) DC-type structure. 


\section{(v) Portability arrangements}

To enhance or fully establish portability there is a range of arrangements that can and is being used. Most portability analysis and discussions focus on bilateral arrangements between two countries but the scope is much larger and is suggested to include the following:

- Unilateral actions (UA): They can be taken by the country where the individual has established acquired rights and they can go a long way to improve portability through full exportability of acquired rights. How much UA can achieve will depend on benefit design. Examples of unilateral actions include (a) Denying access to the national social security scheme (such as in the Gulf Cooperation Council countries for essentially all "expats”, and for some categories of foreign workers in Singapore and Hong Kong); As also no contributions are levied, the individual can establish own rights by contributing in his home country for pensions and health care benefits (for him and his family) such as in the Philippines and in Mexico; (b) Allowing access but on a voluntary basis. In this case the individual can make a choice between contributing in his host or home country with the decision depending on benefit design and exportability; ${ }^{15}$ (c) Allowing the full or at least partial exportability of benefits based on acquired rights. Full exportability can go very far to establish portability for monetary benefits based on financial and non-financial defined contribution design.

- Bilateral agreements (BA): Such agreements are the centerpiece of current portability arrangements between countries. While they can, in principle, cover the whole range of exportable social benefits they typically focus on long-term benefits such as old-age, survivors and disability pensions and to a much lesser extend on health care benefits, if at all. ${ }^{16}$ Yet our knowledge on what is covered by BAs is actually only very partial ${ }^{17}$. On pensions the bilateral agreement can (a) focus on temporary migrants only (e.g. waving the contribution requirement to the pension scheme in the host country while making such contributions mandatory in the home country, as in the US-India agreement); (b) cover all (legal or even illegal) migrants that have established acquired rights. The content of the agreement can be limited to the export of benefits, it can extend to the "totalization" of contribution periods for the calculation of benefits to overcome the effect of vesting periods, but it can also include double (pro-rata) benefit calculation to address issues of final salary and non-linear accrual rates to dampen or avoid a negative impact on benefit level. They are also used to establish

\footnotetext{
15 The Philippines and Mexico fall somewhere between example (a) and (b). The Philippines allow workers to contribute to the national pension schemes but independently of access in host country. Similarly, Mexican migrants can get access to health care benefits for a flat-rate premium (for their families left behind or themselves when returned) independent of their insurance in the host country (i.e. US).

${ }^{16}$ For some historic and legal background on bilateral agreements, see Strban (2009).

17 There is no single study (inventory) that captures the content of bi-lateral agreements across the world or even of sub-regions such as Europe. Reportedly a number of (European) academics in social law wanted to write their Ph.D. thesis on this topic but eventually they gave up. There is also no knowledge, not even on a bilateral basis, how effective such agreements are as no results framework has ever been established nor and any impact evaluation undertaken. This dramatically qualifies our assessment in Holzmann et al. 2005 that characterizes bi-lateral agreements as "best” practice.
} 
benefits in the case of different benefit types between the countries (e.g. residency based basic and contributory schemes). On health care the bilateral agreement can (c) provide emergency access to the health care system only; (d) provide access to basic health care benefits; or (b) allow the full access to the health care benefits with complicated arrangements of compensation.

- Multilateral Arrangements (MA): In this case for a group of countries a general framework of portability for all or a subset of social benefits is established. These general rules are typically supported by further bi-lateral arrangements. The best known and developed MA is among the member states of the EU that continues to be an evolving agenda determined by EU directives and case rulings by the European Court of Justice (ECJ). A specificity of this European social security coordination is the predominance of lawyers specialized in social policy and the virtual absence of economists and social scientists in preparation, debate and writing. Their focus on consistency among different goals and legal framework of the EU provides an interesting (albeit not always easy) reading. What seems totally absent is qualified and rigorous empirical work on how this arrangement is actually functioning and how it affects individuals. And MAs have also been established in Latin America (MERCOSUR), the Caribbean (CARICOM) and, in the future, between Latin America and Spain and Portugal (Ibero-American Social Security Convention.). The EU is also leading efforts to enhance social security cooperation within the Euro-Mediterranean Partnership (EMP). ${ }^{18}$ Social security agreements with Algeria, Morocco, and Tunisia have been concluded under this initiative. And preparations of such agreements may exist in other parts of the world. Again while there is knowledge about the legal framework there is very little information and empirical analysis of their actual functioning. But this applies to also to bi-lateral agreements.

- Multinational Providers (MP): To achieve portability of social benefits, in particular for pension and health, a promising approach may be to use more the services of multinational providers, at least for supplementary benefits. They exist and function well for health care benefits (such as Van Breda, a Belgium service provider, for World Bank staff and retirees residing in Europe, and is also used by the European University Institute). Such MP arrangements have been under discussion, at times implemented, for supplementary pensions of international workers in multinational enterprises. Any future policy discussion of portability should include an analysis of the expansion of such services by MP.

${ }^{18}$ Algeria, Egypt, Israel, Jordan, Lebanon, Morocco, Syria, Tunisia, Turkey and the Palestinian Authorities. 


\section{Benefit Design and Portability Arrangements - Pensions}

This section applies the conceptual framework of the prior section to (old-age) pension benefits. The key purpose is to gain a better understanding on the most critical elements in pension scheme design that impede portability; the role, scope and limits of portability arrangements to overcome those impediments; and the role of benefit design in establishing full portability in a regional setting. To this end this Section starts out with an application of the analytical framework developed in Section 3 to public pension benefits. This is followed by an application of benefit design review and portability arrangements in a multi-pillar pension framework. It ends with a proposal of establishing full portability in a regional setting.

\section{(i) Actuarial Fairness of Pension Benefits and Portability}

A key conjecture of the proposed framework in Section 3 is that portability of pension or any other social insurance benefits can be improved or even full established, if the 3 key components - insurance, savings, and redistribution - can be clearly distinguished within an actuarial framework and agreements between countries established accordingly.

Abstracting initially from redistribution, the actuarial value of old-age benefits under a social insurance approach can be formally defined, the net savings amount/accrued to date liability calculated, and portability established.

Equation [3.3] in Section 3 provides a presentation of the (actuarial) saving component for an individual at any arbitrary age ã before retirement under an old-age social insurance scheme.

$$
S(\tilde{\mathrm{a}})=\sum_{a=1}^{\tilde{\mathrm{a}}} s(a)(1+r)^{\tilde{\mathrm{a}}-a}=\sum_{a=1}^{\tilde{\mathrm{a}}}[c(a)-E[\mathrm{~b}(a)]](1+r)^{\tilde{\mathrm{a}}-a}=C(\tilde{\mathrm{a}})-B(\tilde{\mathrm{a}})
$$

As a reminder, $c(a)$ is the contribution, $E[b(a)]$ the expected benefits, and $s(a)$ the savings component at age a $\leq \tilde{a}, C(\tilde{a}), B(\tilde{a})$ and $S(\tilde{a})$ the accumulated values at age ã, and $r$ the (actual or notional) rate of return provided by the system and consistent with the macroeconomic budget balance. The expected benefit E[b(a)] prior to retirement in an old-age insurance scheme can be a disability or survivor's benefit or zero if such benefits are provide via separate schemes that are individually priced. True to a social insurance scheme, the risk profile and hence the insurance component - E[b(a)], B(ã) - reflects the average for the population.

With these contributions the individual's acquires right for a stream of expected future pension benefits $b(a)$ from retirement age $a_{r}$ onward. Valued at age ã the present value can be written as

$$
B^{e}(\tilde{\mathrm{a}})=\frac{B^{e}\left(\mathrm{a}_{\mathrm{r}}\right)}{(1+\mathrm{r})^{\mathrm{a}_{\mathrm{r}}-\tilde{\mathrm{a}}}}=\left[\sum_{a=\mathrm{a}_{\mathrm{r}}}^{\mathrm{a}^{\mathrm{d}}} \frac{b(a)}{(1+r)^{a-\mathrm{a}_{\mathrm{r}}}} \sigma\left(a_{r}, a\right)\right] /(1+r)^{\mathrm{a}_{\mathrm{r}}-\tilde{\mathrm{a}}}
$$

with $\sigma$ the survival probability from retirement $a_{r}$ to age $a$.

If the system is actuarially fair, the present value of future benefits in [4.2] needs to equal the value of accumulated savings in [4.1] for an actuarial equilibrium. Put differently, 
$\mathrm{B}^{\mathrm{e}}(\tilde{\mathrm{a}})$ is the acquired right (accrued to date liability of the scheme) for an individual at age ã. In order to be fully financed (and actuarially fair), this amount must be matched by the accumulated value of individual and contribution-based (actual or notional) savings S(ã).

We can be a bit more specific about the stream of benefits when specifying an initial benefit at retirement $b\left(a_{r}\right)$ that is indexed with an annual growth rate $g$ and rewrite the actuarial equilibrium condition accordingly.

$$
\left.S(\tilde{\mathrm{a}})=b\left(a_{r}\right) \sum_{a=\mathrm{a}_{\mathrm{r}}}^{\mathrm{a}^{\mathrm{d}}} \frac{(1+g)^{a-\mathrm{a}_{\mathrm{r}}}}{(1+r)^{a-\mathrm{a}_{\mathrm{r}}}} \sigma\left(\mathrm{a}_{\mathrm{r}}, a\right)\right] /(1+r)^{\mathrm{a}_{\mathrm{r}}-\tilde{\mathrm{a}}}=b\left(a_{r}\right) G(g, r, \sigma) /(1+r)^{\mathrm{a}_{\mathrm{r}}-\tilde{\mathrm{a}}}
$$

with $\mathrm{G}(\mathrm{g}, \mathrm{r}, \sigma)$ as function in growth rate (indexation) of pensions, the interest rate, and the survival probability measured from retirement. Selecting $g$ and $r$ at equal level, $G$ is simplified to the (conditional) life expectation at retirement.

Equation [4.3] can be rewritten to exhibit how the initial benefit needs to be selected to achieve equilibrium. This boils down to divide the accumulated (actual or notional) savings by the $G$ function and this approach to calculate the initial annuity is used by defined contribution systems (be they fully funded or notional).

[4.4a] $b\left(a_{r}\right)=\frac{S(\tilde{\mathrm{a}})(1+r)^{\tilde{\mathrm{a}}-\mathrm{a}_{\mathrm{r}}}}{G(g, r, \sigma)}$

But the same approach can, in principle, also be used for a defined benefit scheme (funded or notional) and a translation (or re-casting) of the accrued to date liability into an actuarially fair benefit stream. In many cases both will not coincide.

[4.4b] $b\left(a_{r}\right)=\frac{B^{e}(\tilde{\mathrm{a}})(1+r)^{\tilde{\mathrm{a}}-\mathrm{a}_{\mathrm{r}}}}{G(g, r, \sigma)}$

Both [4.4a] for DC schemes or [4.4b] for DB schemes can be used to establish actuarial fairness and hence full portability of old-age pensions across borders. Under equal setting, the individual as well as the sending or receiving would be indifferent if the pension were to be paid out in the future by the sending country or would receive a transfer and move the resources amounting to the accumulated savings or accrued to date liability to the receiving country.

In most country systems that are typically of NDB type, the actuarial condition as formulated in [4.3] is no fulfilled as the systems exhibit main redistributive features at the level of contributions, at the level of benefits, and their non-actuarial linkage. Hence to achieve balance a residual redistributive component $\mathrm{R}(\tilde{\mathrm{a}})$ is introduced that can be positive (i.e. a transfer) or negative (i.e. a tax) for the individual.

$$
S(\tilde{\mathrm{a}})+\mathrm{R}(\tilde{\mathrm{a}})=b\left(a_{r}\right) G(g, r, s) /(1+r)^{\mathrm{a}_{\mathrm{r}}-\tilde{\mathrm{a}}}
$$

This redistributive component for an individual may represent redistribution within a cohort or generation and hence a deviation from some average that is actuarially fair and financially sound. For example the benefit formula may favor low income groups through contributive advantages and flat rate or progressive benefit formula. In this case $R(\tilde{a})$ is positive for individuals below some reference average and negative for those 
above. And there are good arguments to make both savings component S(ã) and redistributive component $\mathrm{R}(\tilde{\mathrm{a}})$ fully portable before retirement and the insurance component $\mathrm{B}(\tilde{\mathrm{a}})$, or what it is left, after retirement. They all reflect acquired rights that are financially sustainable. Hence, a transfer will not make the individual, the sending and a potential receiving country worse off.

The portability issues becomes less straight forward if the redistributive component is financially highly unsustainable, and the system needs a comprehensive reform with direct impact on the expected benefit level. In consequence the acquired rights that are recognized at the time of migration are not well defined. This is of little consequence if the migrant will or is receiving his or her pension abroad from the former receiving country as a reform-induced reduction in benefit level would hit him (or her) as well. It is potentially different for transfer amounts taken along with migration that include the savings as well as the redistributive component. While there should be little problem for the (actual or virtual) savings component under a DC scheme, the redistributive component may be an issue if large as this risks to leave the sending country worse of while making the migrant better off compared to the non-mobile nationals. This issue is prevented with a fully fletched (funded as well as notional) DC scheme with a balancing mechanism that ensures solvency.

\section{(ii) Application of Benefit Design Review and Portability Arrangements in a Multi-pillar Pension Framework}

As noted earlier, to assess portability obstacles it is important to review all pillars that constitute the pension system of a country, and multi-pillar pension design is being adopted in an increasing number of countries (Holzmann and Hinz, 2005). In this paper we compress the presentation to three pillars (Table 4): Basic pension (in the form of demogrant and means-tested minimum income guarantee); mandated earnings related pensions (funded and unfunded); voluntary and funded supplementary pension. Within each pillar Table 4 identifies in the first column key constraints for portability that result from legal restrictions, are linked to benefit design or result from taxation rules. The second column identifies the potential losses that are linked with the constraints. The next four columns to the right sketch the key actions that can be taken under the identified portability arrangements to address portability restriction in order to increase or fully establish portability.

Basic pensions in the form of demogrant (i.e. basic provisions granted because of residency and independent of other income or assets) exist only in a few countries such as Canada, Iceland, Mauritius, Netherland, and New Zealand. Portability should, in principle, not be an issue as it can be easily established on a pro-rata or threshold basis. Guaranteed minimum income schemes in the form of means-test social pensions and similar social assistance-type schemes that provide a floor exist in many more countries, including in the developing world such as Botswana, South Africa, and Namibia (see Holzmann-Robalino and Takayama, 2009). In low and middle income countries with typically low coverage they serve as the main instrument of old-age retirement income provisions for the elderly needy. The higher the income level of countries and hence coverage rate the more the minimum income guarantee serves to supplement for low contributory pensions. Such guarantees reflect the social policy concerns for low-income 
groups that are country-specific and needs based and as a result are typically excluded from being portable - for reasons of country-specific social objectives and circumstances, fiscal fairness and the avoidance of welfare arbitrage. A solution exists in reciprocity contracts between countries. While only the pension based on acquired rights is made portable, individuals get access to the income guarantee when they take residency in another country covered by the agreement (an approach emerging under the new 2004 EU directive). A special issue emerges if the change in residency by a retiree is contingent by the new host country on having sufficient income for support (such as requested the EU; see Verschueren, 2009).

Earnings-related pensions should, in principle, create no obstacle for portability as making pensions based on the acquired rights fully portable is consistent with individual and fiscal fairness. The main constraints emerge due to national decisions to exclude migrant workers from contributing to the scheme or disallowing the export of pensions, design features of pension benefit design, and tax regulations. Lacking access of (temporary) migrants to the pension scheme of the host country is not strictly a portability issue as it allows individuals to contribute to schemes in their home country or save on a voluntary basis. If they cannot or do not want to do so then it becomes a social policy issues as they may lack coverage when old. In a number of cases it is the home country that starts negotiating with the host country for such exemptions in order to avoid contribution losses in the absence of a bilateral agreement (of totalization) as in the case between India and US. Difficult to justify but easy to address is the prohibition of benefit export, or if permitted, the reduction on pensions in payment (such as the 30 percent reduction for German pensions exported to countries outside the EU and for which not bilateral agreement exists). The prohibition of export is a case where international rules should become binding to make eligible rights fully exportable. The reduction of exported benefit levels to take account of differences in purchasing power is a more complicated matter - both conceptually and operationally. A very recent and interesting example concerns the decision by the French Constitutional Council that lifted 3 articles discriminating the benefit levels for former soldiers ("anciens combatants") between nationals and foreigners while recognizing the right to apply different coefficients depending on differences in purchasing power and cost-of-living in countries were such pensions are paid (if it is applied for all eligible residents in a non-discriminatory manner). ${ }^{19}$ By January 1, 2011 new legislation is required for non-discriminatory benefit levels.

Most of the relevant constraints for portability and also the main content of bi-lateral and multi-lateral agreements to overcome them seem to emerge from the specific benefit design features of DB schemes. Three interrelated design characteristics are critical: vesting, final salary, and non-linear accrual rates (see also Forteza, 2008).

- Vesting conditions as the minimum contribution period (years) required for benefit eligibility exist in all DB-type schemes. Some minimum vesting period (say a few months) may make sense for administrative and cost reasons (albeit at a time of computerization this is becoming less relevant) and too low annuity levels resulting

\footnotetext{
${ }^{19}$ Le Monde, Samedi 29 mai 2010: Le Conseille constitutionnel censure pour la première fois des lois en vigueur”. Page 1 et 10 .
} 
from only a few years of contribution can be addressed by full reimbursement of collected contributions. In most DB schemes the vesting period is in the range of 10 to 15 years but can reach as high as 30 years as in the case of Argentina. The logic behind such long vesting periods is the non-actuarial structure and a favoring of individuals with lower contribution levels and records and often also the provision of minimum benefit guarantees. Vesting should thus prevent gaining access to such advantages with only a few years of contribution. Partial or full benefit losses through (high) vesting periods are addressed with totalization provisions that aggregate all contribution periods between countries for which bi-lateral or multilateral agreements apply. Alternatively, vesting periods could be virtually eliminated by the move toward an actuarially benefit structure (such as a DC-type scheme but can also be replicated in DB systems, including the distributive features); actuarial benefit structures eliminate the rationale for vesting except for very short periods of contribution.

- Using final salary (or the best of salaries from a limited number of years) to determine the pensionable income base and hence the benefit level creates losses for a mobile worker compared to his immobile (social insurance) sibling. Such a benefit design (instead of using revalued average earnings till retirement) makes the benefits back loaded and in consequence moving leads to benefit losses. The historic origins are civil servant schemes that were first replicated in white-collar scheme, including the seniority principle in salary setting. Replication of last salary features in bluecollar schemes is not an advantage for workers as their wage profile is typically hump-shaped with a much earlier peak than white-color workers. In now mostly joint general schemes last salary features continue profiting the later starters/high risers over the early starters/low risers. But many recent pension reforms have typically included a lengthening of the assessment period to 25 years or more, or full lifetime earnings.

- However, unless DB schemes full mimic DC schemes (including an earnings base over the full active life-cycle that is revalued with average wages) effects of backloading and benefit losses for the mobile worker will remain. To avoid or at least reduce losses linked with the benefit formula is addressed in agreements through double calculations - of an independent benefit in each country for the relevant insurance period (ignoring vesting as totalization applies), and of the pro-rata benefit in each country by applying the totalized insurance period for each scheme, calculating the theoretical pension amount and then apportioning for the relevant insurance period. Individuals under such agreements are entitled to receive the higher of independent and pro-rate benefits from each country's pension institution. The pro-rata benefit calculation has been confirmed by the EU Regulation 883/2004 as the principle among member states. But not all bi-lateral or multi-lateral agreements include double calculation; many restrict to totalization and some only to exportability of benefits. While double-calculation reduces benefit losses for mobile workers it cannot eliminate all of them if they are linked to back-loading, incomplete revaluation, and non-actuarial structures. Eliminating these effects requires a change in benefit design and the move toward DC or actuarial DB structures. 
Table 4: Multi-pillar Benefit Design and Portability Arrangements

\begin{tabular}{|c|c|c|c|c|c|}
\hline $\begin{array}{l}\text { Pillars (and Benefit Types) } \\
\text { Portability constraints }\end{array}$ & $\begin{array}{l}\text { Potential } \\
\text { individual loses }\end{array}$ & $\begin{array}{l}\text { Unilateral Action } \\
\text { (UA) }\end{array}$ & $\begin{array}{l}\text { Bilateral } \\
\text { Agreements } \\
\text { (BA) }\end{array}$ & $\begin{array}{l}\text { Multilateral } \\
\text { Arrangements } \\
\text { (MA) }\end{array}$ & $\begin{array}{l}\text { Multinational } \\
\text { Providers } \\
\text { (MP) }\end{array}$ \\
\hline \multicolumn{6}{|l|}{$\begin{array}{l}\text { Basic pension: Demogrant and } \\
\text { minimum income guarantee }\end{array}$} \\
\hline Not exportable & $\begin{array}{l}\text { Loss in basic } \\
\text { pension }\end{array}$ & $\begin{array}{l}\text { Make demogrant } \\
\text { exportable on pro-rata } \\
\text { basis }\end{array}$ & $\begin{array}{l}\text { Reciprocity; } \\
\text { Totalization of } \\
\text { residency \& benefit } \\
\text { recalculation }\end{array}$ & $\begin{array}{l}\text { Reciprocity; } \\
\text { Totalization of } \\
\text { residency \& benefit } \\
\text { recalculation }\end{array}$ & \\
\hline \multicolumn{6}{|l|}{$\begin{array}{l}\text { Mandated earnings-related } \\
\text { benefits (first \& second pillar) }\end{array}$} \\
\hline $\begin{array}{l}\text { No access to social security in } \\
\text { host country (NDB, DC) }\end{array}$ & $\begin{array}{l}\text { From none to } \\
\text { access to any } \\
\text { pension }\end{array}$ & $\begin{array}{l}\text { Contribution in home } \\
\text { country }\end{array}$ & & & $\begin{array}{l}\text { Contribution to } \\
\text { MP }\end{array}$ \\
\hline $\begin{array}{l}\text { Voluntary access, not exportable } \\
\text { (NDB, NDC) }\end{array}$ & $\begin{array}{l}\text { From non to access } \\
\text { to any pension }\end{array}$ & $\begin{array}{l}\text { Contribution in home } \\
\text { country; } \\
\text { Reimbursement of } \\
\text { contributions }\end{array}$ & $\begin{array}{l}\text { Reciprocity; } \\
\text { totalization; benefit } \\
\text { recalculation }\end{array}$ & $\begin{array}{l}\text { Reciprocity; } \\
\text { totalization; benefit } \\
\text { recalculation }\end{array}$ & $\begin{array}{l}\text { Contribution to } \\
\text { MP }\end{array}$ \\
\hline $\begin{array}{l}\text { Access but not exportable (NDC, } \\
\text { NDB) }\end{array}$ & $\begin{array}{l}\text { Loss in contribution } \\
\text { payment/pension } \\
\text { benefit }\end{array}$ & $\begin{array}{l}\text { Make exportable } \\
\text { Reimbursement of } \\
\text { contributions }\end{array}$ & $\begin{array}{l}\text { Totalization; } \\
\text { benefit } \\
\text { recalculation }\end{array}$ & $\begin{array}{l}\text { Totalization; benefit } \\
\text { recalculation }\end{array}$ & \\
\hline $\begin{array}{l}\text { Access, exportable with penalties } \\
\text { (NDB, NDC) }\end{array}$ & $\begin{array}{l}\text { Loss at the level of } \\
\text { penalty }\end{array}$ & Eliminate penalties & $\begin{array}{l}\text { Totalization; } \\
\text { benefit } \\
\text { recalculation }\end{array}$ & $\begin{array}{l}\text { Totalization; benefit } \\
\text { recalculation }\end{array}$ & \\
\hline Vesting period (NDB) & $\begin{array}{l}\text { From non (if not } \\
\text { binding) to loss } \mathrm{f} \\
\text { any pension }\end{array}$ & Move to NDC & Totalization & Totalization & \\
\hline Last salary formula (NDB) & Back-loading gains & Move to NDC & $\begin{array}{l}\text { Benefit } \\
\text { recalculation }\end{array}$ & Benefit recalculation & \\
\hline Non-linear accrual rates (NDB) & $\begin{array}{l}\text { Loss or gain } \\
\text { depending on } \\
\text { accrual rate scale }\end{array}$ & Move to NDC & $\begin{array}{l}\text { Benefit } \\
\text { recalculation }\end{array}$ & Benefit recalculation & \\
\hline
\end{tabular}




\begin{tabular}{|c|c|c|c|c|c|}
\hline Top-ups not exportable & Loss of top-ups & Grant export & Reciprocity & Reciprocity & \\
\hline Taxation policy & $\begin{array}{l}\text { From gains to non } \\
\text { to double-taxation }\end{array}$ & & Reciprocity & $\begin{array}{l}\text { Harmonized tax } \\
\text { treatment (EET, TTE) }\end{array}$ & \\
\hline \multicolumn{6}{|l|}{ Voluntary funded benefits } \\
\hline Vesting period (FDB) & $\begin{array}{l}\text { From non to full } \\
\text { loss in pension }\end{array}$ & Move to FDC & & & $\begin{array}{l}\text { Contribution to } \\
\text { MP }\end{array}$ \\
\hline Last salary formula (FDB) & $\begin{array}{l}\text { Loss in back- } \\
\text { loading gains }\end{array}$ & Move to FDC & & & $\begin{array}{l}\text { Contribution to } \\
\text { MP }\end{array}$ \\
\hline Non-linear accrual rates (FDB) & $\begin{array}{l}\text { Loss or gain } \\
\text { depending on } \\
\text { accrual rate scale }\end{array}$ & Move to FDC & & & $\begin{array}{l}\text { Contribution to } \\
\text { MP }\end{array}$ \\
\hline $\begin{array}{l}\text { Taxation policy (e.g. different } \\
\text { taxation rules; no tax deduction for } \\
\text { premium paid abroad) }\end{array}$ & $\begin{array}{l}\text { From gains to non } \\
\text { to double-taxation }\end{array}$ & $\begin{array}{l}\text { Allow tax deduction for } \\
\text { contributions paid to } \\
\text { abroad }\end{array}$ & Reciprocity & $\begin{array}{l}\text { Harmonized tax } \\
\text { treatment (EET, TTE); } \\
\text { deductbility }\end{array}$ & \\
\hline
\end{tabular}

Source: Authors 
- Last but not least, non-linear accrual rates will create non-neutrality of the benefit structure for mobility decisions. But in this case losses as well as gains can be created and the incentives may go in both directions - encouraging or discouraging mobility. Many unreformed DB schemes have decreasing (annual) accrual rates decreasing from say, 2 percent for the first 20 years of contribution to 1 percent for any year above. Hence in this case working 20 years in each country provides a much higher benefit for the mobile worker compare to immobile one for constant wages. Linked with final salary benefit calculation reduces such advantages or may even reverse them. Bi- or multi-lateral agreements may address such distortions but are unlikely to eliminate them. Again, moving toward an actuarial benefit structure (DC or DB) allows eliminating them.

A potentially important but largely uninvestigated fairness and efficiency concern for portability may be created by the supplements to earnings-related pensions for lower income groups to which many migrants belong. Such needs-determined supplements or top-ups include minimum pension benefits, diverse allowances (e.g. for housing, heating, telephone) as well as special prices for seniority citizen, and most or all of these top-ups are not exportable. Anecdotal evidence has it that these non-exportable top-ups codetermine the decision of migrants to stay in North albeit their family live in the South and their pension is exportable. ${ }^{20}$

For mandated earnings-related pension benefits bi- and multilateral arrangements are seemingly ways to address many but not all fairness and efficiency concerns. Furthermore, such agreements have not yet been subject to any evaluation about their functioning. While such evaluations need to be undertaken and are strongly encouraged, the available information and evidence suggests that bi- and multilateral arrangements are unlikely to comply fully with the fairness and efficiency criteria established above. This suggests investigating in parallel the alternative of moving toward a more actuarial benefit structure (augmented by explicit redistributive features, as deemed useful). The trade-off between national social policy objectives and international mobility objectives seems to be small and decreasing as essentially all recent pension reforms move in this direction.

Portability concerns emerge also for voluntary (third) pension pillars that are gaining increasing importance: To compensate for reduced public generosity - a trend that will continue, and to provide more room for individual retirement decisions - for example bridging the period to an increased retirement age by own saving. Both aspects are of particular relevance for high income groups that are typically also more mobile.

Portability issues for voluntary pensions prior to retirement are typically linked to DB design in occupational pensions and regulatory and tax issues in both occupational and personal (tax-qualified) pensions. Occupational DB pensions with their vesting and back-loading features that risk to impede within-border mobility have attracted attention for a long time in a country context; with increased mobility across countries portability issue of occupational pensions have also received more attention, including in the EU (see, e.g. Andrietti, 2001). Cross-border portability of occupational pensions is of

\footnotetext{
${ }^{20}$ Such anecdotes furthermore suggest that key determinants for non-return include social capital
} considerations in both North and South (see Jeunne Afrique, 2009). 
relevance also for migrants from outside the EU: In a number of EU member countries are occupational pensions fully part of the national pension system design (such as in France, Denmark, Netherlands, Sweden and the UK) and migrants have a higher EUinternal mobility than nationals. Despite this strong interest in the cross-border portability of occupational pensions within the EU, progress has been slow and seems now stalled at a time when non-statutory pensions are gaining importance (Verschueren, 2009). The difficulty of coming-up with EU-wide regulations are linked with the diversity and complexity of occupational schemes within and across countries, their voluntary nature which raises hesitations to burden employers by complex and possible expensive regulations, and the political resistance at EU Council level for more coordination and streamlining.

If portability of occupational pensions within the EU cannot be assured, the chances for successful arrangements between countries in the North and South are even less promising. If formal arrangements do not work, what are the alternatives? There are essentially two:

- Moving toward a more actuarial benefit structure that reduces the need for coordination. The good news is that most new pension promises by enterprises are nowadays of DC-type structure that takes away most but not all mobility constraints.

- Increasing the scope for multi-national (service) providers in the area of supplementary pensions. Some multi-national enterprises have created such entities in order to address the supplementary pension issue for the mobile work force. Such multiemployer entities could be created at regional or even international level, be subject to centralized supervision and create an innovative tax arrangement with the participating countries. Thinking outside the box is required ...

\section{(iii) A Regional Framework for Pension Portability}

To address fairness and efficiency concerns for the production of and trade in goods and services within regional areas of integration, the value-added tax system had been created by the (predecessor of the) EU but implemented since also in many other countries across the globe. The VAT system creates a framework for taxing of goods and services that is neutral for domestic production and consumption decisions while allowing countries to fix their own contribution rates and hence allow for an autonomous fiscal policy stance. The VAT system has importantly contributed making the EU an integrated economic area and delivering on two of the 4 freedoms. To guarantee also freedom of movement of labor across the EU and to inspire neighboring countries to join the approach the development of an equivalent framework seems required. Hence we are looking for a portability framework for pension benefits that creates fairness and efficiency while allowing (member) countries to continue autonomously determining the level of benefits and hence the financing requirements (contribution levels). The proposed key elements of such a framework for pensions (old-age, disability, and survivors) are the following (for more details, see Holzmann, 2006):

- A multi-pillar pension approach with NDC schemes at its core and social pensiontype (basic) and voluntary (occupational and personal) FDC-type (supplementary) provisions at its wings. 
- For most European pension systems the transformation of their Bismarckian DB-type scheme into a NDC scheme would be straight forwarded and is suggested in any case in order to address population aging and the need for neutrality on labor market decisions (including retirement age).

- The adoption of a common NDC approach would allow full portability of acquired rights across professions within borders (e.g. between civil servants and private sector workers) as well as for all professions across borders. Acquired rights (value of individual accounts) could be kept in each country, are wage revalued through the notional interested rate and transformed into a pension at retirement applying remaining life-expectancy. Alternatively the individual account' value is transferred with the mobile worker when crossing the border to a new job and when a new individual account is created. Between countries only the net flows for all movers need to be cleared.

- Countries can decide on the level of overall contribution rate and also a possible split between statutory NDC and FDC schemes.

- For the basic pillar countries would be free to establish a minimum income guarantee (social pension) and its integration with the statutory earnings-related pension. While such guarantees may not be exportable, reciprocity agreements would be able to establish fairness and efficiency.

- For the voluntary pillar benefit portability within a common FDC framework would be very much facilitated. To go the whole mile would require some common framework for tax treatment (such as on taxation principle such as EET and crossborder contributions). But alternatives to explore include also the use of multinational pension service providers.

Having such a framework for pension portability for a regional setting in place and tested may also inspire neighboring countries to review, adopt and join. 


\section{Benefit Design and Possible Portability Arrangements - Health Care}

Health care benefits share a number of similarities with pension benefits but exhibit also additional features that renders the portability of health care benefits significantly more complex than portability of pensions. This may be the reason why comprehensive arrangements for the portability of health care benefits across countries are still more the exception than the rule. Yet, we claim that the application of the framework developed in Section 3 may provide a basis to overcome many of the obstacles, at least to offer an analytical benchmark to facilitate the development of an operational portability approach. But to be successful will require further analytical work and empirical research. This Section starts out by comparing the similarities and differences of pension and health care benefits followed by an application of the framework with step-wise introduction of complexity within a model setting. This is followed by a presentation of data and different cases to bring the concept to live and a review of existing approaches. We end with outlining some of the policy challenges related to enhancing the portability of health care benefits and a proposal for next steps of investigation.

\section{(i) Similarities and Differences between Pension and Health Care Benefits}

Pension and health care benefits share a number of similarities, most importantly:

Prefunding: Health care benefits are also characterized by a major (actual or notional) savings component. While benefits are accessed also early in the life cycle, the majority of expenditure happen later. With flat or earnings-related contributions this leads to a major accumulation of savings that typically peaks also around the age of retirement.

Redistribution: The redistributive component of health care benefits is quite likely at least as high, and in many cases much higher than for pensions. The redistributive elements enter at the level of contributions that are in many health care systems wage based while the benefits are risk based. And redistributive elements enter also at the level of benefit provision through survivor's benefits for pensions and health care benefits for family members that are often not separately priced.

Benefit costs: Both benefit types are exposed to differences in the purchasing power/cost of living between home and host countries. This has a potential impact on the relative value of any savings component that may be transferred and the value of goods and services that can be purchased.

In addition, health care benefits exhibit a number of complexities that create main differences from pension benefits, most importantly:

Benefit package: Pension benefits are relatively simple-structured. The benefit is a monetary amount and once its initial value is established it changes typically only in line with some index formula related to wages and/or prices. Health care benefits are, in principal, open ended. And even when a basic health care benefit package is defined it will vary substantially across countries and over time.

Risk profile: The common risk profile across both benefits is the survival probability (related to mortality). In addition, health care benefits are exposed to health-specific risk 
profiles (related to morbidity) that vary substantially across individuals. This impacts what part of the health-care package is needed and the intensity with which it is used.

Family benefits: Both benefit types provide family benefits - survivor's benefits and health care benefit for dependent family members. However in the case of health care the access to benefits may, in principle, be distributed between host and home country in case the family of the migrant stays behind. But in few cases such an access is provided which raises the question how they are best covered.

\section{(ii) Applying the Framework to Health Care Benefits}

The challenge of portability of health care benefits is in a first instance the result of asymmetric information, revelation of an individual's true health risks with age, and redistributive considerations. Otherwise, individuals could purchase an actuarially fair insurance in each period (in host and home country) as per equation [3.1] and hence buy a new insurance each time they migrate to a new country. However, as the expected benefit increases typically with age because of higher health risk and therefore more intensive benefit usage, the health insurance premiums do so likewise. This could, in principle, be addressed with personal pre-saving. Yet, as with age some individuals move from being a good (low) to being a bad (high) risk-bad risks often entailing catastrophic costs - the premium eventually may become un-financeable for the latter if a contracting insurance company can be found at all. Even if it could be financed, presaving for a risky event does not allow welfare-optimal consumption smoothing as at the end too little or too much will have been saved. For this reason mandated risk pooling in a social health insurance has been established in most countries that charges a community-rated health insurance contribution, as opposed to an experience-rated premium that takes individual health risks into account. The mandated contributions are levied in a flat or earnings related manner over the life cycle that are largely divorced from the risk profile giving rise to a savings as well as a redistributive component.

Abstracting initially from the complications outlined above, the actuarial value of heath care benefits under a social insurance approach can be formally defined, the net savings amount calculated, and portability established. ${ }^{21}$

Equation [3.3] from Section 3 provides a presentation of the (actuarial) saving component for an individual at any arbitrary age ã. This is the amount that can be made portable for the migrant moving from home country to host country, between host countries, and eventually back to the home country without making the home country worse off.

$$
\text { [5.1] } S(\tilde{\mathrm{a}})=\sum_{a=1}^{\tilde{\mathrm{a}}} s(a)(1+r)^{\tilde{\mathrm{a}}-a}=\sum_{a=1}^{\tilde{\mathrm{a}}}[c(a)-E[\mathrm{~b}(a)]](1+r)^{\tilde{\mathrm{a}}-a}=C(\tilde{\mathrm{a}})-B(\tilde{\mathrm{a}})
$$

As a reminder, $c(a)$ is the contribution, $E[b(a)]$ the expected benefits, and s(a) the savings component at age a $\leq \tilde{a}, C(\tilde{a}), B(\tilde{a})$ and $S(\tilde{a})$ the accumulated values at age ã, and $r$ the (actual or notional) rate of return provided by the system and consistent with the aggregate solvency condition.

\footnotetext{
${ }^{21}$ For a more complete analytical treatment of the different risks involved, see the companion paper by Werding and McLennan (2010).
} 
True to a social health insurance scheme, the risk profile and hence insurance component $\mathrm{B}(\tilde{a})$ reflects the average for the population. Any distributed mortality gains (as some individuals will have died and lose their savings component) and morbidity gains (as some individuals will be healthier and spend less than their savings component even when living a long time) are reflected in the sustainable rate of return $\mathrm{r}$.

In the receiving (host or home) country a transferred savings amount serves to balance the difference between the present value of expected benefits and contribution for the remainder of the live cycle till death (as per equation [3.5]).

[5.2] $S(\tilde{\mathrm{a}})=\sum_{a=\tilde{\mathrm{a}}+1}^{\mathrm{a}^{\mathrm{d}}} \frac{b(a) p(a)}{(1+r)^{\mathrm{a}-\tilde{\mathrm{a}}+1}} \sigma(\tilde{\mathrm{a}}+1, a)-\sum_{a=\tilde{\mathrm{a}}+1}^{\mathrm{a}^{\mathrm{d}}} \frac{c(a)}{(1+r)^{\mathrm{a}-\tilde{\mathrm{a}}+1}} \sigma(\tilde{\mathrm{a}}+1, a)=B^{e}(\tilde{\mathrm{a}}+1)-C^{\mathrm{e}}(\tilde{\mathrm{a}}+1)$

with $b(a)$ the price of the health care benefit package at age a, $\mathrm{p}(\mathrm{a})$ the probability of its use and $\sigma$ the (conditional) survival probability.

Equation [5.2] is the actuarial condition for any age cohort within a country. Hence, as long as the risk profiles are largely similar, the contributions in home and host countries are levied in a similar manner, the migrant represents a fair selection of both populations, and the benefit package is of similar size and price, the new and old risk pool would not be better or worse off by transferring the saving component with the migrant. Hence portability of health care benefits could be fully established.

In what follows we relax some of these simplifying assumptions one by one, investigate the implications for actuarial fairness and portability, and outline first considerations.

Different risk profiles: What happens to actuarial fairness and portability if the new member is known to be a bad risk? In order to assure actuarial fairness, would this need to be compensated by a higher transfer amount from the home country? In principal yes, but it is not clear whether the bad risk profile necessarily leads to higher expected expenditure as the expected higher benefits $\mathrm{E}[\mathrm{b}(\mathrm{a})]$ at all ages need to be assessed against the lower survival probabilities of a bad risk. There is limited empirical research on this topic but available studies suggest that at least for retirees being healthy does not lead to lower remaining lifetime health care costs - on the contrary (see Sun, Webb and Zhivan, 2010). This is the result of higher life-expectancy of the healthy, but because of this also a higher probability of a chronic disease as well as requirement for a nursing home both of which are expensive. Nevertheless, the expected expenditures of bad versus good risks also have to be compared to expected contributions, which could be substantially lower for bad risks because of limited earnings potentials and lower survival rates. Ultimately, the net balance of expected contributions over expenditures of bad versus good health risks at different ages would have to be compared for a complete analysis. Such an analysis would then also have to take into account potential adverse selection issues whereby bad risks - knowing about their true health status - might decide to migrate to countries with better health packages.

Different contribution profiles: Under equal conditions in host and home country the contribution profile can be flat over the life cycle, say a given share of average wage or average health expenditures, or, as in social health insurance schemes, a share of the individual wage, leading to a major redistributive component R(ã) at migration age ã. 
[5.3] $S(\tilde{\mathrm{a}})_{i}+R(\tilde{\mathrm{a}})_{i}=C(\tilde{\mathrm{a}})_{\mathrm{i}}-\mathrm{B}(\tilde{\mathrm{a}})+R(\tilde{\mathrm{a}})_{i}=B^{e}(\tilde{\mathrm{a}}+1)-\mathrm{C}^{\mathrm{e}}(\tilde{\mathrm{a}}+1)_{\mathrm{i}}$

The redistributive component can be substantial. Say the considered individual i earns his whole life half of the average income. As the contribution needed to finance the average benefit package is at the level of the average income payer, $R_{i}(\tilde{a})$ amounts to the size of his or her accumulated contribution effort $C_{i}(\tilde{a})$. To ensure that neither home nor receiving country is made worse off, the redistributive component would need to be also transferred/made portable.

As long as migrants are an unbiased selection of the population in home and host country and wage and hence contribution levels are equivalent both risk pools would not be affected. Yet, migrants often are among the lower paid individuals in the host country as the host country has typically a well educated, high-productivity labor force. As a result for the home country as it receives a larger transfer compared to the expected future benefits. The reverse is true for the departure from a lower income home to a higher income host country.

Different price of health care package: So far we had assumed the same price for such a health care package in host and home country. Richer host countries have typically a more comprehensive and expensive package price, even for basic provisions. Hence transferring the full amount of the saving component from a richer host country $h$ would lead to a windfall profit for the poorer home country $m$ while leaving the risk pool in the host country indifferent. The reverse is true for the migration initially moving from the home country to the host country at mid-career.

[5.4] $S_{i}(\tilde{a})_{h} \geq B^{\mathrm{e}}(\tilde{\mathrm{a}}+1)_{\mathrm{m}}-\mathrm{C}^{e}(\tilde{\mathrm{a}}+1)_{\mathrm{m}}$ iff $\mathrm{b}(\mathrm{a})_{\mathrm{m}} \leq \mathrm{b}(\mathrm{a})_{\mathrm{h}}$

Reducing the savings component to the level of the expected benefits net of contributions in the home (and return) country would leave the home country risk pool indifferent and establish full portability for the migrant as no impact on the return migration decision should take place. However, if the benefit package in the return country is less good he or she may still have an incentive to stay in the home country. This may offer an argument to allow for an in-kind or cash transfer to the returned migrant, either through selective access to the health care benefits in the former host country, to high-quality health care services in the home country (but paid by the host country, or a simple lump sum cash benefit, up to the aggregated value of the difference in equation [5.4].

Family benefits. Social health insurance provides a major redistributive component through the typically cost-free insurance of dependent family members (mostly spouse and children). As the insurance value of the benefit package is defined for the average family size, the redistributive component for an individual depends on the size of their family and their access to the benefits:

[5.5] $\mathrm{R}_{\mathrm{i}}(\tilde{\mathrm{a}})=B_{i}(\tilde{\mathrm{a}})-B(\tilde{\mathrm{a}}) \leq \geq 0$

If the migrant has his family with him or has access to the benefit package from the host country, the redistributive element will depend on the family size. For the first generation the family size is typically above the average of the nationals in the host country. However, most host countries do not extend health care benefits to family left in 
the home country leading to a negative redistributive component. This may offer an argument to co-pay up to this amount toward a health care package in the home country.

\section{(iii) Life-Cycle Contributions to and Expenditures of Social Health Insurance}

Available data across the world strongly indicate that health expenditures over the lifecycle significantly depend on age. Taking Austrian data to illustrate, annual health expenditures in 2003 on average ranged from less than EUR 500 for 10 -year olds to over EUR 4,000 for 85-year olds (Figure 2). This compares to average annual contributions of about EUR 2,100 for employees. If contributions were constant over age groups, actual expenditures would reach actual contributions only around the age of 60. At younger ages, contributions would exceed age-specific expenditures. As a result, average workers are net-contributors to the health system up to the age of 60, and net-receivers thereafter. From an individual perspective health insurance financing includes an important presaving element.

Other countries with financing models different from social health insurance have similar implicit pre-saving elements. Switzerland, for example, applies a flat contribution rate towards private, competing insurers. As can be seen in Figure 3 premiums exceed net costs up until the age of 60. Tax-financed universal health systems, like in the United Kingdom, will most likely display similar expenditure features that can be compared the age profile of general taxes. Other county examples, as can be found in Werding and McLennan (2010) for Germany and Slovenia, display similar contribution and expenditure profiles.

Figure 2. Austria: Average annual health care expenditures and contribution profile by age group in 2003 (EUR)

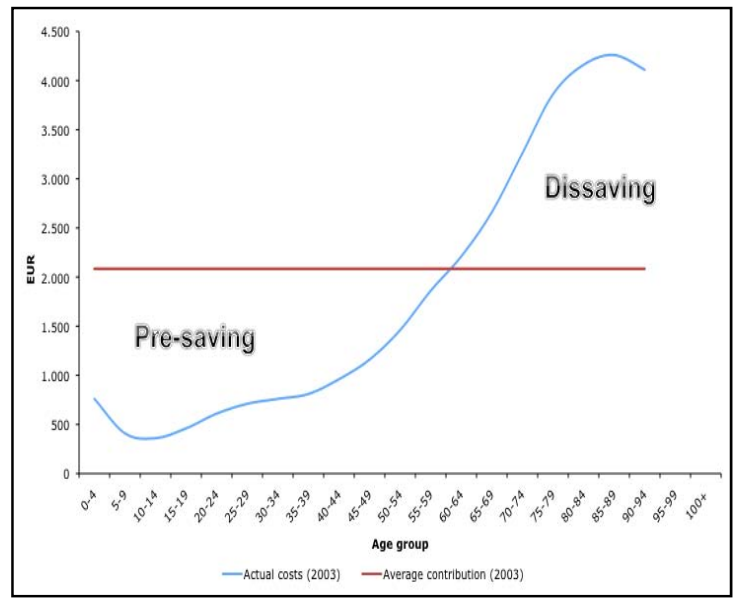

Source: Hofmarcher and Rack (2006)
Figure 3. Switzerland: Average monthly health costs (net and risk adjusted) and premium profile by age groups for male members in 2006 (SF)

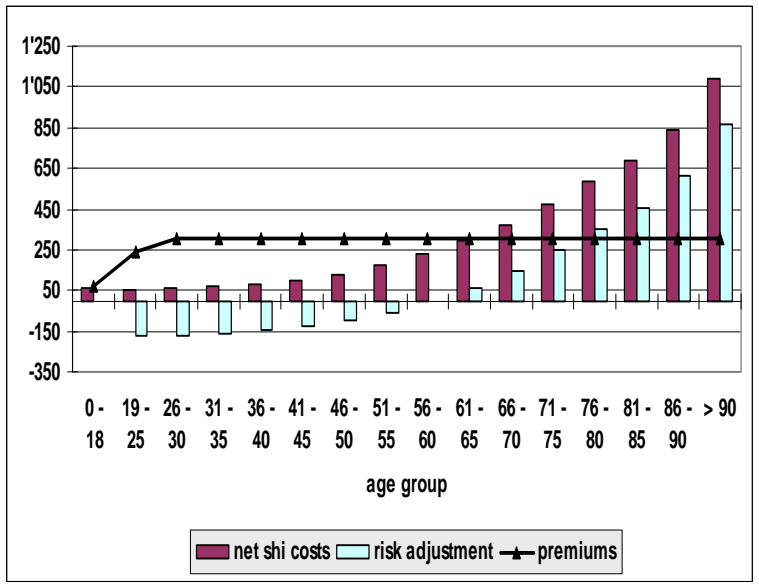

Source: World Bank (2009)

To the extent that wages increase with age, contributions to social health insurance also increase with age. This could potentially reduce some of the pre-savings and bring contributions more in line with actual expenditures over age groups. At the same time, because earnings are higher at older age, the "break-even" age when contributions equal expenditures is also shifted outwards. Overall, the break-even point will most likely be 
around retirement age, when earnings fall significantly while expenditures are still increasing strongly. Hence, effectively social health insurance redistributes from the active to the inactive population in a cross-sector consideration while shifting resources from young to old in a life-cycle consideration. In other words, social health insurance has an implicit pre-saving element that has to be taking into account when designing portability arrangements. In order to do, the pre-saving element has to be made more explicit. Notional health accounts could be a means to achieve this.

\section{(iv) A simple model of notional health accounts and challenges of portability between countries}

Notional health accounts serve to determine the average pre-saving element for individuals, based on their age-specific contribution and expenditure histories. Such an approach would abstract from differences in individual risk and contribution profiles; rather, the pre-saving element would be determined by calculating average contributions and health expenditures for each age cohort and each year. The difference between average contributions and expenditures for a certain age cohort is then the net pre-saving element credited to an individual (and his health notional account) for a particular year, and these annual credits (or debits for older age groups) accumulate throughout an individual's life.

Table 5 presents a stylized example of such a notional health account for an individual living for 10 periods. When starting to contribute at young ages, expenditures are low while earnings are also relatively low, but higher than expenditures. Every period the individual therefore earns a positive saving credit $s(\tilde{a})$. As the individual ages, contributions increase significantly with earnings while health expenditures also slowly grow each period. Up until period 7, the individual has accumulated a sizable savings element $S(\tilde{a})$. In period 8, the individual retires and stops contributing, while health expenditures continue to increase. Until the individual's dies at age 10, the accumulated savings serve to finance health expenditures. By the time of the individual's death, savings are back to zero.

If the individual moved to another country at any given age $\tilde{a}=a$ ', the individual could simply transfer the accumulated savings $S\left(a^{\prime}\right)$ into the social health insurance of the host county and full portability would be established. The accumulated savings together with future contributions are sufficient to cover future health expenditures in the host county, so the risk pool in the host country is not affected, neither positively nor negatively. Similarly, the risk pool of the home country does not enjoy a windfall profit from the individual leaving savings behind-just like in the host country, the risk pool in the home country is not affected because the migrant transfers the accumulated savings to the host country.

Full portability, though, hinges on the assumption that the home and the host countries are similar with regard to (i) health contributions and expenditures as well as the value and quality of health benefit packages. In addition, it assumes that actual migration flows are unbiased with regard to (ii) health risk profiles and (iii) characteristics that have an impact on redistributive policies, including family benefits. The following subsections will relax these assumptions one by one. 
Table 5: Stylized expenditures, contributions, and savings for an individual living, contributing, and benefiting for 10 periods

\begin{tabular}{lrrrrr}
\hline $\begin{array}{c}\text { Age } \\
\tilde{\boldsymbol{a}}\end{array}$ & $\begin{array}{c}\text { Expenditure by age } \\
\boldsymbol{b}(\tilde{\boldsymbol{a}})\end{array}$ & $\begin{array}{c}\text { Contribution by age } \\
\boldsymbol{c ( \tilde { a } )}\end{array}$ & $\begin{array}{c}\text { Saving credit by age } \\
\boldsymbol{s}(\tilde{\boldsymbol{a}})\end{array}$ & $\begin{array}{c}\text { Accumulated savings by age } \\
\boldsymbol{S}(\tilde{\boldsymbol{a}})\end{array}$ \\
\hline $\mathbf{1}$ & 5 & 10 & 5 & 5 \\
$\mathbf{2}$ & 10 & 35 & 25 & 30 \\
$\mathbf{3}$ & 15 & 55 & 40 & 70 \\
$\mathbf{4}$ & 20 & 65 & 45 & 115 \\
$\mathbf{5}$ & 25 & 75 & 50 & 165 \\
$\mathbf{6}$ & 35 & 85 & 50 & 215 \\
$\mathbf{7}$ & 50 & 75 & 25 & 240 \\
$\mathbf{8}$ & 80 & 0 & -80 & 160 \\
$\mathbf{9}$ & 90 & 0 & -90 & 70 \\
$\mathbf{1 0}$ & 70 & 0 & -70 & 0 \\
\hline Sum & 400 & 400 & 0 & \\
\hline
\end{tabular}

Note: Table 5 presents a stylized example of a typical individual living, contributing to, and benefiting from a health care insurance for 10 years. At age 1, the individual starts working and contributing to health insurance. Since the individual is relatively healthy at this age, he or she is contributing more than benefiting, so at each year, credited savings are positive and accumulated savings start to build up. At age 8 , the individual retires and starts to consume considerable benefits without contributing, drawing down accumulated savings. After the end of age 10, the individual dies with zero savings left.

Source: Authors

\section{Differing contribution and expenditure profiles}

The main challenge to establish international portability of health benefits through notional accounts is arguably the wide variety in contribution and expenditure profiles of health insurance systems across countries - both in terms of the level (how much?) and shape (how steep?) of profiles over the life-cycle. These originate from differences in (i) income levels; (ii) morbidity and mortality; (iii) health systems; and (iv) quality of health care.

Differing income levels are likely to imply that both contribution and expenditure levels differ importantly from one country to another. As a consequence, migrants' accumulated savings are also likely to differ from country to country and risk being either too low or too high when arriving in the host country. The risk pool of the host country will be negatively (positively) affected by the arrival of the migrant when the migrant's savings are too small (too large).

Even when countries have roughly the same income level, differing morbidity and mortality will lead to differing expenditure profiles. Countries with higher morbidity also have higher health expenditures. The effect of mortality could be more ambiguous because shorter lives to some extent also mean lower health expenditures. Nevertheless, there might be important related effects on earnings potentials and hence contributions. ${ }^{22}$

Also, differing health systems are likely to lead to considerable differences in expenditure and contribution profiles even between countries of the same income level. Contributions rates and bases differ significantly between countries: in some, contributions are entirely

${ }^{22}$ The impact of differing morbidity and mortality is discussed below in more detail. 
based on labor income, in others health systems are entirely financed from general taxation. At the same time, health expenditures covered by health insurance can also differ substantially across countries: for example, health risks covered under one country's health insurance might not be under another or not to the same degree, resulting in differing co-payments. All of these differences affect contribution and expenditure profiles over age-cohorts and therefore the saving component of notional health accounts.

Differing quality of health care between countries, finally, can affect migrants even if expenditure and contribution profiles were exactly identical in the home and host country. This issue is somewhat analogous to the issue of purchasing power of pensions, which also differs across countries. Savings from one country could allow migrants to consume similar packages of health benefits across countries, yet the quality of these health packages might vary substantially between countries. In other words, contributions and expenditures within health insurance systems in two countries might be exactly the same, but what one pays for and spends on in one country might still be of lower quality than in the other country.

Let us consider two examples of migrants moving between countries to illustrate these points. First, consider a young migrant in a high-income country who will later return to the low-income home country for retirement. This migrant might arrive in the host country at age 20 and will contribute to and spend in the host country's health system for some time, being credited savings on the migrant's notional health account every year. This way, the migrant-just like any native worker-will build a history of credits that are in line with what his or her specific age cohort has paid net into the health care system on average. When migrants return (or move on to another country), they could simply take with them any accrued savings. So, when arriving in the host country, the migrant accumulates savings in the host country (at a high level), and then takes the total savings back to the home country when retiring, just as illustrated in Figure 4.

The most important issue in this case is the difference in income levels in the two countries, which leads to high contributions and expenditures - and most likely, high savings - in the host country relative to the home country. If the migrant were to transfer all of his or her savings to the health system of the home country when returning for retirement, the risk pool of the home country would gain a windfall profit. The migrant's savings from the host country far exceeds the expected value of future dissaving of the migrant in the home country. At the same time, the quality of health care in the lowincome host country is probably much below that of the host country. In principle, this excess savings should be paid out to the migrant, who can then also use this payout to purchase additional, high-quality health care in the host country-if available. 
Figure 4: Illustration of pre-saving and dissaving elements over an individual's lifecycle (Case 1 with migration at young age and return for retirement)

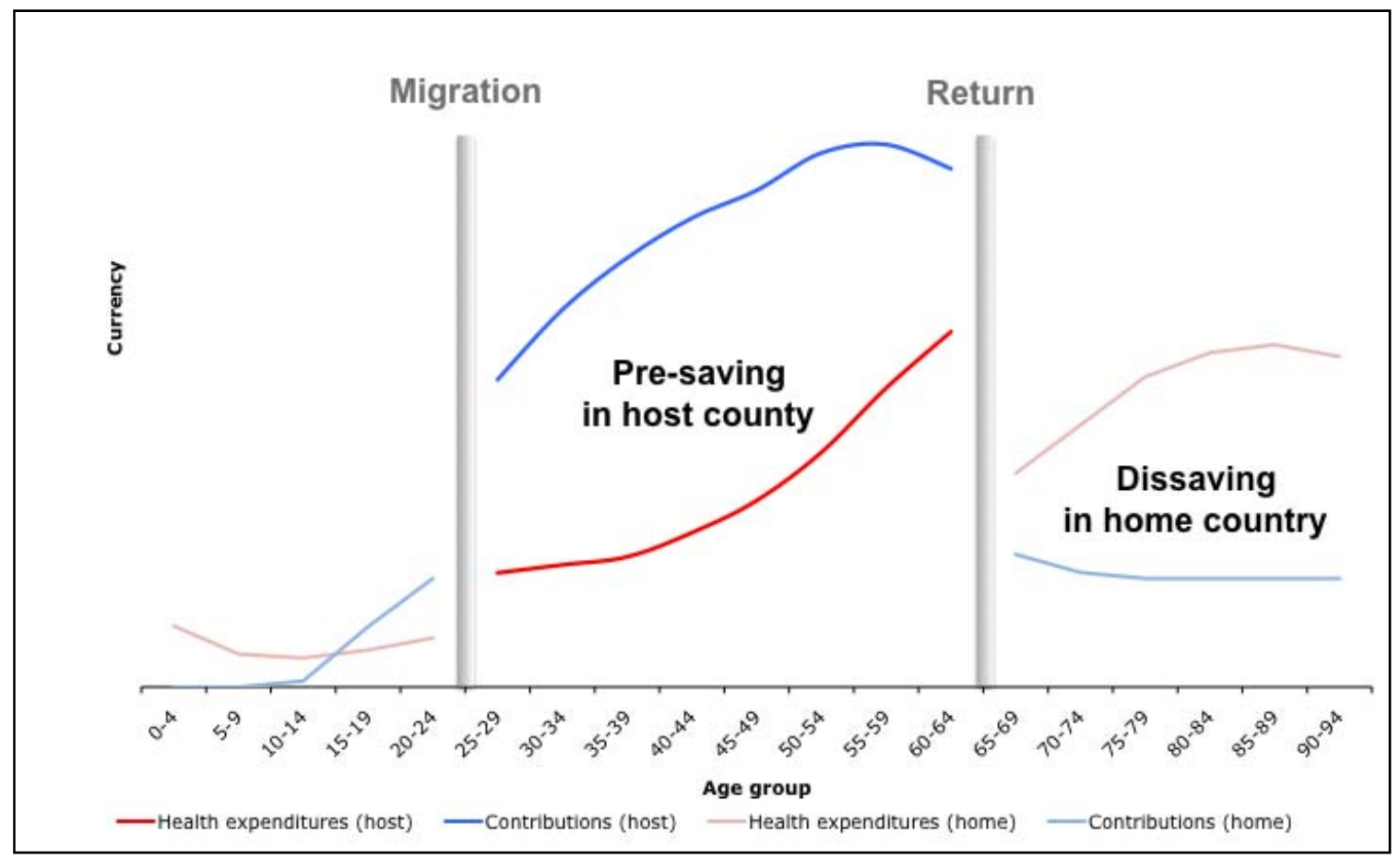

Source: Authors

Figure 5: Illustration of pre-saving and dissaving elements over an individual's lifecycle (Case 2 with late migration and no return for retirement)

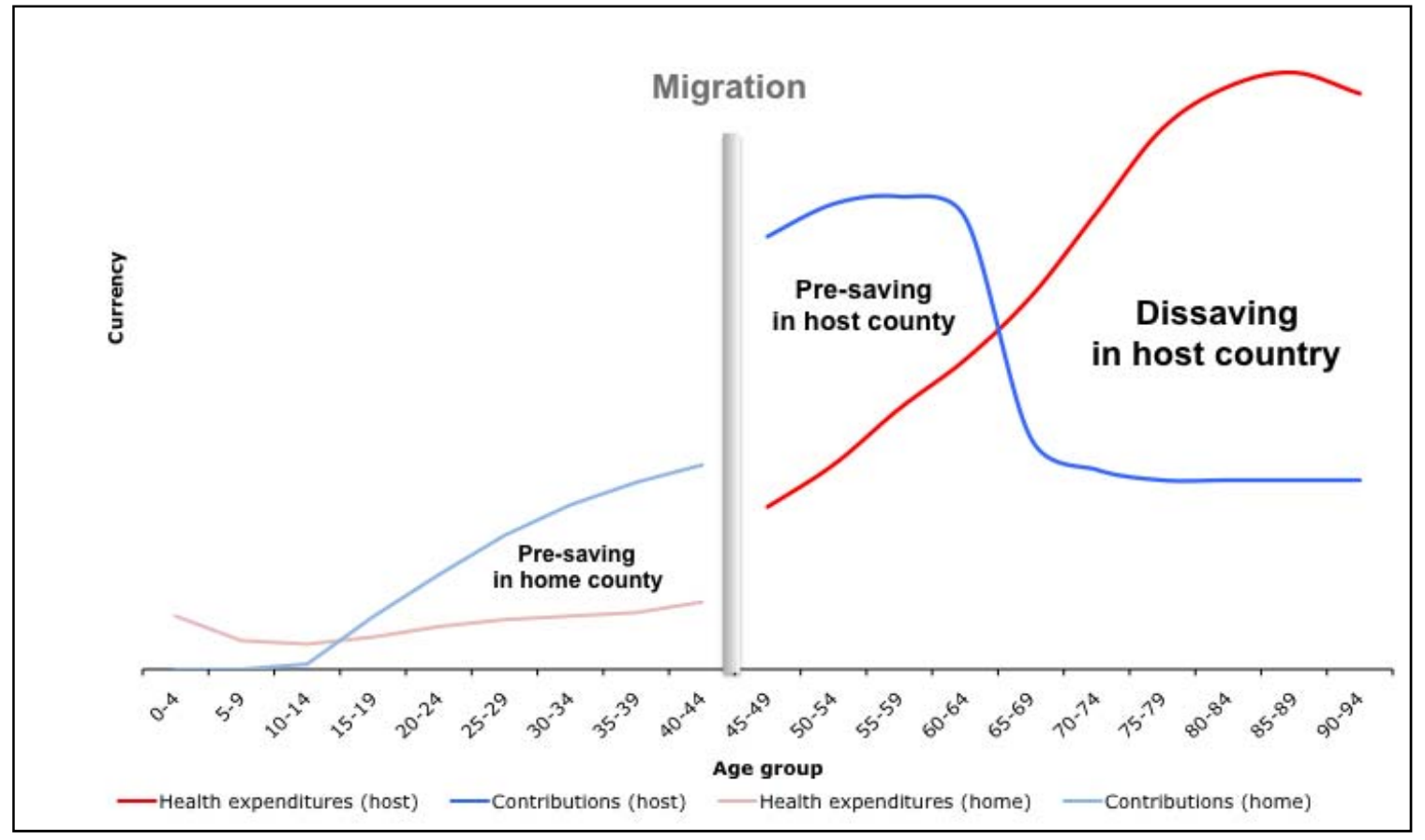

Source: Authors 
A second example is that of a middle-aged migrant from a low-income country who will not return to the home country for retirement. The migrant leaves the home country relatively late, say around the age of 40 , and will stay in the host country also for retirement (see Figure 5). In this case, the migrant contributes and spends at low levels under the health insurance system of the home country for some time. The value of accumulated health account savings is likely to be relatively low. In particular, the savings from the home country would be small compared to an individual with a similar contribution history in the host country. To be actuarially fair, it would actually be necessary to reimburse the health insurance of the host country for the lacking savings due to the absence of the migrant in younger years. Otherwise, the risk pool of the host country would be negatively affected by the arrival of the migrant because his or her savings are not sufficient to cover the deficit between future contributions and expenditures of the migrant. In other words, to be actuarially fair, the migrant should be liable for this lack of savings and pay an additional "joining fee" when arriving in the host country.

The above examples clearly show the importance of the age when migrants arrive in the host country because it determines how high their liability towards the health system of the host country is. The issue of the second example is the same as in the first example: the differences in income levels between the home and the host country lead to differing savings accumulation which are not easily compatible when moving between countriesthey are either too high or too low. In the first case, savings are too high, so in principle, they could just be paid out as a lump sum to the migrant. By the same token, though, savings are too low in the second case, and migrants should then be liable to pay a "joining fee".

The latter case is certainly much more contentious and raises moral and legal concerns: Can migrants be denied access to social health insurance when they are not capable or willing to pay such a joining fee? This would be especially problematic for elderly migrants who arrive relatively late in their career or during retirement, as their joining fees would be particularly high. From a legal and political perspective, the issue is mostly one of anti-discrimination. What, for example, would be the rules for nationals who are outside the health insurance systems and want to join at a latter point? Would the same rules apply or not - that is, would they also be obliged to pay a joining fee according to their age ${ }^{23}$ In practice, the issue could be somewhat mitigated by spreading out payments of the joining fee over a prolonged period of time - up to various years—or even put it on hold in case the migrant has firm intentions to stay temporarily only.

\section{Unbiased migration flows with regard to health risk profiles}

The concept of notional health accounts as proposed is based on community-rated risks, not experienced-rated risks. That is, it does not take into account individual health riskslike, for example, an individual's actual health expenditures—but rather credits savings based on average contributions and expenditures across the same age-cohort. Individual

\footnotetext{
${ }^{23}$ This would of course not apply to those who have left employment or not started employment, but have been covered by health insurance through other means - either through parents (in the case of students), a spouse (in the case of one-earner couples), or through other social security institutions (in the case of unemployed or social assistance recipients).
} 
health risks are not being taken into account, which is in line with the principles of social health insurance systems.

As long as the health risk profiles of migrants who join the health insurance of the host country are similar to those of natives, migrants will display expected future health expenditures similar to those of natives. Yet, if the health risk profiles of migrants are better (worse), the risk pool of the host country will be positively (negatively) affected. By the same token, the reverse could happen to the risk pool of the home country: if migrants have relatively better health risk profiles than the rest of the population of the home country, the risk pool of the home country will be negatively affected by the departure of the migrant. In other words, it matters what kind of risks are moving due to migration: if good risks are migrating, the risk pool of the host country benefits, and the risk pool of the home country suffers; the opposite holds when bad risks are moving.

In the long run, this could lead to problems of adverse risk selection. If migration flows are relatively large and the selection of migrants is unbiased, migrants will mirror the average risk profiles in terms of morbidity and mortality as the rest of the home country's population, in which case the risk pool of the home country is not affected by their departure. For the host country, though, two problems could occur: first, the average health risk profile of migrants from a particular country might be worse than that of the host country. ${ }^{24}$ Then, on average, inflow from that particular country could negatively affect the risk pool of the host country. Second, even if risk profiles of the two countries are similar, if the selection of migrants is biased towards worse risks, the risk pool of the host country could be negatively affected (and the one of the home country positively). Such a bias could be due to adverse risk selection: on the one hand, individuals with bad health risks could chose to migrate to countries with better health systems; on the other hand, countries could chose to only accept migrants with better health risks, thereby improving the quality of their risk pools (cream skimming).

Problems of risk selection are arguably not a major concern when it comes to international migration. Migrants' main motivation to migrate-at least while young -is probably not health concerns, but the search for better earnings opportunities. ${ }^{25}$ Neither do host countries select immigrants on health criteria (aside from some criteria related to public health concerns). Nevertheless, as the experience of the United States (and other high income countries) shows, when individuals are free to chose among different health insurance plans (or base their employment decisions on health benefits), there are problems of risk selection. To the degree that populations become more mobile also internationally in the future, this could become a more pronounced problem for health systems.

Finally, none of these issues would matter if the migration flows between the two countries in question were symmetric. That is, even if migrants from one country were on average worse health risks than the native population of the host country, if a similar "biased" migration outflow from the host country towards the home country would occur,

\footnotetext{
${ }^{24}$ As already mentioned, the relationship between mortality and actual health expenditures is not straight forward: higher mortality could actually mean lower life-cycle health expenditures because of the shortened life period, but he actual relation and the interaction with morbidity is complex.

${ }^{25}$ For older migrants and those returning to their home country, the quality of health care might play a significant role, though.
} 
the effects would cancel out. This could, to some extent, be the case for migration flows in homogenous regions like the EU or and certain regions with large migration flows in the developing world. Nevertheless, the large migration flows between developing and developed countries are unlikely to be symmetric; they are rather unidirectional, from developing to developed countries.

\section{Unbiased migration flows with regard to characteristics that have an impact on redistributive policies}

Last but not least, differences in redistributive policies will pose challenges to achieving portability of health benefits through notional health accounts. In most (social) insurance systems, the following redistributions are observed: (i) from high to low income earners; (ii) from households with no or few dependents (like spouses and children) to those with more; and (iii) from young to old. The redistribution per se does not pose a challengethe savings elements that are being credit to notional health accounts are based on averages, and on average of course redistribution cancels out. Yet, as in the previous subsection, challenges arise when migrants who are different from the average enter or leave risk pools. As already mentioned in the previous sections, in order to leave the risk pools unaffected, an additional transfer would be necessary that compensates, for example, the risk pool of the host country when a relative low-wage earner or a family with relative many dependents arrives. At the same time, though, the risk pool should also pay out a compensation for those migrants who are above average - that is, the highwage earners, the singles, and the young. As before, though, these issues only arise when migrants from a particular country on average are above or below the risk pool of the home or sending country.

Regarding redistribution from high to low-income earners, if migrants from a particular country on average enter the host country as low (high)-income earners, ceteris paribus the risk pool of the host country is negatively (positively) affected because average contributions decrease (increase). The effects on the risk pool in the home country are ambiguous because it is not clear that low-income earners in one country would also be low-income earner in another country. In fact, it could even be that on average migrants are high-income earner in the home country-meaning their departure negatively affects the risk pool of the home country-while at the same time being low-income earners in the host country, negatively affecting also the risk pool there.

Regarding redistribution from households with no or few dependents to those with more dependents, again the issue is how migrants on average compare to the average of the risk pool. In other words, how many dependent, non-working family members do migrants bring with them when they arrive in the host country-more or less than the average of the native population? If it is above the average, it could potentially negatively affect the risk pool of the host country. The reverse holds for the risk pool of the home country.

The issue of redistribution from young to old is a bit more complex, but crucial given the demographic development in many countries. Notional health accounts assume that contributions and expenditures balance over an individual's life cycle on average. In practice, though, health systems are set up as pay-as-you-go (PAYG) systems where current contributions finance current expenditures, with limited possibility to create significant reserves. That is, the surpluses of the current active population finance the 
expenditures of the inactive population. If the inactive population becomes relatively large - like during the demographic transition — and no reserves have been built up from the contributions of the elder generation previously - the young have to contribute more to finance the expenditures of the old. In other words, the life-cycle expenditures and contributions are out of balance, with the young contributing more than they will spend, resulting in redistribution from the young to the old.

The extent of the redistribution can be decreased by spreading it out over future generations in the form of debt. At the same time, countries can also mitigate the individual burden on the young by taking in young migrants. This would happen at the expense of the home country - but only if the home country is in a similar demographic situation. If, to the contrary, the home country is relatively young and there is no or little redistribution to the old, it could actually afford the departure of young migrants. And in the future, this reduction of the youth bulge in the home country today could actually help to reduce the pains of the demographic transition several decades down the road. ${ }^{26}$

It is not clear at this point how any of the compensations related to redistributive policies could be administered in practice. A first step would therefore rather be to assess how important the redistributive elements are-that is, to assess how different are migrants' health, income, family, and age profiles from the averages of home and host countries? Various attempts have already been made in receiving countries in the OECD to assess the impact of immigration on social welfare spending, including health insurance. ${ }^{27}$ Most studies conclude that the decisive factor is the age at which migrants arrive in the host country: the younger, the more contributions over the life-cycle migrants will make in host countries, and the more positive the fiscal impact of migration. Since most migrants indeed arrive in host countries at relative young ages, the overall fiscal impact of immigration into OECD countries - especially those that are relatively far advance in the demographic transition - is likely to be positive. In that sense, discussions on compensations for the redistributive impact or differences in health risks profiles of migrants might not be a priority in high-income host countries. To the authors' knowledge, no such comprehensive studies have been made for sending countries in the South, so the impact on risk pools in sending countries is less well understood.

\section{Some practical considerations}

Finally, there are many statistical issues associated with individual health accounts. This starts from the required significant statistical capacities in both host and home country, goes on with the need to disentangle costs from expenditure in a heavily subsidized setting of public health care and achieving an earmarking of expenditure and revenue to cohorts, and does not end with the need to identify the redistributive element of health care provisions. While this sounds very challenging and at times insurmountable, it will be not different for any other approach that attempts to establish some portability of health care benefits across countries. The proposed approach of separating the insurance, pre-saving and redistributive component and the concept of notional health accounts offers a framework for such an effort. And the framework is claimed to offer a transparent approach to determine issues and trade-offs.

\footnotetext{
${ }^{26}$ This is essentially the idea behind demographic arbitrage.

${ }^{27}$ See for example Kirdar (2010), Australian Government (2003), and Storesletten (2003).
} 


\section{(v) Current Portability Arrangements}

How have countries addressed these tradeoffs so far and what could be done in the future? Currently, there are very few bilateral or multilateral portability arrangements for health care benefits. More importantly, and in contrast to pension benefits, there are also main obstacles on the unilateral level that prevent portability of health benefits. At the same time, this also means that it is probably the unilateral level where most progress could be achieved at this point.

Most countries do not cover treatments abroad without prior authorization. The U.S. Medicare program, which covers health expenditures for retirees, is a good example. Although beneficiaries may have contributed for many years, if they migrate during their retirement, they will lose all coverage. ${ }^{28}$ Similarly, many EU countries do not cover health expenditures that occur outside the EU. Retirees who, for example, would like to move to a third country — like Morocco — are by and large not reimbursed for their health expenditures there. ${ }^{29}$

An exception is the Austrian social health insurance, which grants partial reimbursement for health care costs of out-of-network providers-including all foreign providers. The reimbursement rate, though, is low at only 80 percent of what the same treatment would have cost with an in-network provider in Austria. Claims are handed in directly with the Austrian health insurance, which is not very practical for migrants living outside of Austria. There are no reports of any direct contracting with foreign providers.

On the (multilateral) EU level, there has been more progress, and there are some examples where the same principles developed on EU level have been extended to bilateral agreements with non-EU countries. Within the EU, migrants have full access to health insurance in their country of residence, conditional on national legislation. ${ }^{30}$ Overall, though, there are no financial flows between countries that reflect a transfer of the aforementioned pre-saving element. The only examples where one country would compensate another for health expenditures are: First, for essential health care treatments of health insurance members of one country who are on a temporary stay in another country, so basically tourists and other short-term visitors. ${ }^{31}$ Second, for retirees who reside in an EU country from which they receive no pension. In that case, the health insurance of the country from which the retiree receives his or her largest pension will compensate the health insurance of the country of residence. This compensation can be done in two ways: First, through a semi-annual transfer to the health institution of the retiree's country of residence. The amount is determined in semi-annual meetings at EU

\footnotetext{
${ }^{28}$ The U.S. Medicare program is actually an example of a health care program where the pre-saving element is more explicit: contributors are not covered by health insurance, but contribute towards health insurance during retirement. In that sense, it is actually more like a pension benefit.

${ }^{29}$ In some cases, retirees who give up residency in the EU but receive a pension from an EU country, lose health care coverage in the EU, but their pension might still be subject to health contributions.

${ }^{30}$ In most countries, access to health insurance is conditional on employment. In some countries, it is conditional on residency (where there is a universal health system).

${ }^{31}$ Essential health care treatments means emergency treatments and all treatments that cannot reasonably be postponed until return to the home country.
} 
level and is based on actual health expenditures for retirees in the respective country of residence. Second — and increasingly more common - the actual health expenditures of the particular retiree are transferred regularly, based on actual invoices. ${ }^{32}$

The same principles have been applied in bilateral agreements between German and Austria on the one side, and Turkey and the countries of the former Yugoslavia on the other. To the authors' knowledge, there are no other multilateral or bilateral agreements that cover the portability of health benefits. ${ }^{33}$

\section{(vi) Conclusions: Challenges, Potential Solutions, and Next Steps of Investigation}

This section has highlighted opportunities and challenges of enhancing the portability of health care benefits and proposed the introduction of notional health accounts as a possible way forward. In short, such notional health accounts would accumulate cohortspecific saving elements to individual accounts for periods individuals have participated in the system. The annual balance at the end of year would be calculated as balance of last year, plus a (notional) remuneration, plus the difference between the average cohort contributions minus the cohort expenditure of that year (corrected for contribution gaps within the year by the individual). The (notional) remuneration would be the internal rate of return of the health care system and conceptually equivalent to the notional rate of return in an NDC pension system (see Section 4, and Holzmann, Palmer and Robalino, 2011).

For migrants, the balance on such a notional health account could be transferred to the health system of the new host country. This would not only ensure that the migrant gains access to the health system in the new host country, but also that the risk pool of the new host country's health system is not suffering a financial loss.

Clearly, such an approach would face considerable practical as well as conceptual challenges, of which some have been identified in the previous subsections. Most notably, the following challenges stand out:

First, most migrants leave their home country at young age. They arrive in the host country with no or small liabilities to the health insurance system and will make substantial contributions to the health system (and other welfare programs and general tax system) potentially for a prolonged period of time. The (fiscal) impact of emigration of young migrants on their home country and the health system there is less well understood and deserves additional research. Such research should also focus on the potential of demographic arbitrage - that is, to what extend can young migrants ease the fiscal burden of the demographic transition in developed countries today, while at the same time ease the pains of the demographic transition in developed countries many years down the road.

Second, middle-aged migrants who arrive in their new host country from a low-income country might have relatively small savings on their accounts—at least when compared to

\footnotetext{
${ }^{32}$ For a case study on health care portability arrangements-including financing arrangements—-within the EU, see Obermaier (2009) and also Werding and McLennan (2010).

${ }^{33}$ See, for example, the agreement between Turkey and Germany from April 30, 1964 (BGBl 1965 II S. 1169).
} 
natives of the new host country in the same age cohort. In other words, their net balance is insufficient to join the health system of the new host country. Should these migrants be obliged to pay a "joining fee" that eliminates the gap between their balance and that of their peers in the host country? In principle, yes, but it is not necessarily large.

For temporary migrants, the joining fee could be put on hold initially and only be charged once the migrant decides to stay permanently. For those who do stay permanently, payments could be spread out over large periods of times.

Third, long-term migrants returning for retirement to the home country would have a considerable surplus on their notional health accounts, but may not be able to spend this surplus in the home country because the value of health benefits there is considerably lower. Different options may be available. The migrant could simply receive a lump-sum payout from the health system when leaving the host country. This might enable the migrants to buy the appropriate level and quality of health care he. Many times, though, the level and quality of health care that the migrant wants is simply not available at an affordable price in the home country. In order to address this, some way to ensure (at least partial) access to high-quality health care for migrants also during retirement in the home country is necessary. This could be achieved either by allowing migrants to return to the former host country for health care or by directly developing and contracting highquality health care providers in the home country at the expense of the health system of the host country.

Forth, the health risk profiles, income profiles, and family profiles of migrant might considerably differ from that of the native population in the host country. If migrants are sicker (or healthier), have lower (or higher) earnings potential, have more (or less) children than natives, or are younger (or older), should the risk pool of the host or the home country be compensated, and if so, by whom? More research is needed in this regard, in particular on the impact of migration on risk pools in home countries.

Fifth, the role of private health insurance should be further investigated. Private providers could play a role in improving access to good-quality health insurance across countries. International providers who have the capacity to contract good-quality health care providers across a large number of countries could offer an option to migrants that guarantees them access to good-quality health care, also when returning to their home countries. The problem, though, is that by the time migrants need that type of health insurance, they are relatively old, their true health status has been revealed to a large extent, and as a consequence have accumulated many pre-existing conditions that they cannot cover anymore or only at unaffordable costs.

This issue may be addressed with a "buy-in" option or buy-in plan that gives the right to migrants to buy affordable health insurance at a locked-in rate when needed. Such a health insurance plan — if the option is executed and a health insurance plan is bought would cover all pre-existing conditions that occur after the date of buying the option. The migrant would effectively insure against the loss of a high-quality benefit package in case he or she returns to her home country. It could also be set up as a supplementary health insurance plan that tops up any entitlements from public benefit packages that the migrant has access to in his home country. 
Last but not least, further research is necessary to deepen also the conceptual analysis on how to enhance the portability of health benefits. The analysis presented in the paper is merely a first step that frames the main challenges and offers some first insights. A more detailed analysis is needed to explore these challenges further and to investigate potential reforms. And in parallel a thorough evaluation of existing portability arrangements for health benefits is needed. 


\section{Key Issues for Better Understanding Portability and the Way Forward}

While portability is increasingly seen as a key issue for better migration management and notable progress has been made in our understanding of issues and possible solutions, our knowledge base is still pretty limited. This section sketches perceived main knowledge gaps that need to be closed in order to move to the next stage of portability design and implantation.

Data need: For migration in general and portability in particular there is a dearth of quantitative information. This concerns general demographic information about migrants (and their families in host and home country) as well as the migration and employment status, access to social protection programs and possible portability issues before and after retirement.

Details on portability arrangements, their functioning and effectiveness: While unilateral, bi-lateral and multi-lateral arrangements are public information no comprehensive yet basic study seems to exist that provides information and analysis on benefits covered, coordination mechanism for benefits, admin procedures, etc. To our knowledge also no rigorous empirical information and analysis on actual working of bilateral and multi-lateral arrangements exist. Issues to be investigated would include the share of processed requests compared to potentially eligible beneficiaries; the portability loss prevented by the agreements; an assessment of the process of coordination and key issues, etc. etc. Such investigations would have start out with a results framework to make it useful and successful.

Corridor studies on portability of social benefits: A promising way toward such a results framework would be to undertake a number of corridor studies on benefit portability between countries in the North and South. Such studies are not very cost intensive but would help importantly for our understanding of issues as well as data availability and needs. ${ }^{34}$

Empirical evidence that portability matters: A key tenant for the improved portability is that it matters for labor mobility decisions. But the empirical evidence is pretty thin both in scope of investigation as well as empirical effects. Much of results are from occupation schemes in the US and Europe ${ }^{35}$ while investigation on portability issues of statutory schemes within the EU are virtually non-existent. ${ }^{36}$ To our knowledge there are also no qualified studies for mobility issues of portability between the South and the North (both in The Americas and the Mediterranean region).

Developing a formal analytical framework: Last but not least, in order to render the empirical work and proposed conceptual considerations sound, there is the need to

${ }^{34}$ For first steps in this area see Holzmann et al. (2005), Abdousalam (2009), Sabates-Wheeler and MacAuslan, in print.

${ }^{35}$ These studies could not find evidence that portability losses in occupational schemes in the US and Europe caused lower mobility (Forteza, 2008).

${ }^{36}$ Bonin et al.(2008) assess on a small impact of portability on European labor mobility (compared to language skills, job prospects and culture adaptation. And Aguila and Zissimopoulos (2009) expects from a ratification of the UD-Mexico agreement an increased return migration from older Mexicans. The results by Hoghe et al. (2008) on the drivers for migrants on the selection of European host countries indicate that job opportunities are important not the size of social expenditure (and, perhaps, portability?). 
develop a formal analytical framework. Starting position could be the characterization of a first best social insurance contract that includes job mobility (and the risks involved, including the risk of having to migrate). Into such new general analytical framework the one proposed in this paper separating the insurance, savings and distributive component of social benefits should be folded.

\section{Summing-up and Conclusions}

The paper provides a fresh look on the international perspective of portability of social benefits, a topic that has so far been dominated by social policy lawyers working within the framework of bi- and multilateral. The contribution by economists to the discussion has been limited. This paper offers a conceptual framework for portability analysis and applies the proposed alternative solution of changes in benefit design to pensions and health care.

Summing up, several key elements stand out:

First, labor mobility across professions and borders increases world-wide for various reasons. Whatever the motivation for labor mobility, from a first-best economic point of view and individual labor mobility decisions, from a social policy point and the individual's (or family's) life-cycle planning, and from human rights point of view and the right to social protection, broad portability of social benefits should be established and the eligibility to and disbursement of benefits not depend on the country of residency.

Second, the paper suggests a definition of portability that defines it as the ability to preserve, maintain and transfer vested social security rights or rights in the process of being vested, independent of profession, nationality and country of residency. Hence portability consists of 2 critical elements: The full receipt of vested and eligible social security rights as well as rights under private sector arrangements (benefits in disbursement, health care coverage) based on acquired rights through prior contributions/premiums or residency criteria in any chosen residency; and the full transfer of social security rights as well as rights under private sector arrangements that are in the process of being vested before eligibility has been established based on acquired rights through prior contributions/premiums or residency criteria in any chosen residency.

Third, the paper conjectures that portability issues of social benefits for internationally mobile workers (migrants) emerge from the tension between the more domestically oriented social policy objectives linked to historically grown social risks management objectives and instruments and the more internationally oriented economic policy objectives linked to cross-border labor mobility due to globalization and demographic changes. The tensions reflect more broadly the diverging interests of host country and home countries, and of mobile and immobile labor force. As the latter have a large majority, this creates special issues of the political economy.

Forth, the current approach to address these tensions is through bilateral and multilateral agreements that cover an unknown set of social benefits with no international inventory of the rules applied nor any evaluation of their effectiveness. The very partial information suggests that many of the bilateral agreements focus on old-age pensions and 
related benefits (survivors and disability) and very few on health care and other benefits, if at all (such as family and unemployment benefits, and long term care).

Fifth, and as an alternative approach to address these tensions, the paper proposes a review of the social benefit design and a disentangling of the risk pooling, (notional or actual) pre-funding and redistributive components that are included with varying importance in each social benefit. For eligible benefits in disbursement it is the redistributive component that creates obstacles to export across borders. For benefits in accumulation (i.e. not yet eligible acquired rights) it is both the pre-funding and the redistributive component that create such obstacles. Identifying the pre-funding components of acquired rights and making them transferable across borders would go some way to improve portability. Bi- or multilateral reciprocity agreements would be needed on the export of redistributive components from the old to the new country of residency (in case of social insurance benefits) and on the accessibility of redistributive components in the new country of residency (in case of social assistance benefits). 
Sixth, while the paper presents benefit re-designs and inter-country agreements as alternative approaches to establish portability in order to tease out their scope and limits, both approaches are likely to be re-enforcing and complementary. The better the social benefit components are identified the easier it is for national legislation to allow for the export of benefits in disbursement and transfer of acquired rights (pre-funding) and for inter-country agreements to focus on reciprocity in the redistributive component.

Seventh, while the risk pooling, pre-funding and income redistribution components exist in funded and unfunded, defined benefit and defined contribution-type benefits, the disentangling of these components is much facilitated in the latter (and largely independently of the financing form). And essentially all social insurance-type benefits based on contributions can, in principal, be converted in this direction and the components separated. But not all need to be converted for reasons of portability as a many of them will have limited bearing on labor mobility or life-cycle social risk management. Yet for a number of benefits schemes, in particular pensions and more recently also unemployment benefits, such a benefit re-design is in any case taking place with limited considerations for portability.

Eighth, the separation of risk-pooling and pre-funding is investigated for the dominant social insurance benefits - old-age pensions and health care benefits. For pension benefits such a scheme already exists - the Notional Defined Contribution (NDC) scheme - and has been introduced in a number of countries (such as Italy, Latvia, Poland, Sweden, and Poland), and under implementation in others (Norway and Egypt). The paper sketches the application within an economic area of integration (European Union) in order to establish full portability across borders (and professions). For health care benefits the application of the approach to allow for portability of privately provided health within countries has been analytically investigated but never for publicly provided health care across borders. The analysis in this suggests that it is, in principle, feasible but raises a number of issues and questions for which good answers are not yet always out.

Ninth, and last but not least, the proposed conceptual framework is only the beginning of an intellectual voyage and many empirical and theoretical issues need to be addressed in a next stage. They include data requirements, understanding how current bi-lateral and multi-lateral agreements actually work, including in-depth corridor studies, understanding empirically for which benefits portability really matters and why, exploring the political economy of the approach, and developing a formal analytical framework improve conceptual clarity and allow for ex-ante evaluations.

\section{References}

Abdousalam, Drame. 2009. Access to pension benefits for returned migrants: A corridor case study for Mali-France. World Bank, mimeo.

Aguila, E. and J. Zissimopoulos (2009): "Labor Market and Immigration Behavior of Middle-Aged and Elderly Mexicans.” Working Paper WR-726, RAND.

Australian Government, Department of Immigration and Multicultural Affairs. 2003. The Importance of Age in Migrants’ Fiscal Impact. 
Avato, J., J. Koettl and R. Sabates-Wheeler. 2009. Definitions, Good Practices, and Global Estimates on the Status of Social Protection for International Migrants. Social Protection Discussion Paper No. 0909. Washington, DC: World Bank. [http://siteresources.worldbank.org/SOCIALPROTECTION/Resources/SPDiscussion-papers/Labor-Market-DP/0909.pdf]

Avato, J., J. Koettl and R. Sabates-Wheeler. 2010. "Social Security Regimes, Global Estimates, and Good Practices: The Status of Social Protection for International Migrants”, World Development 38, No. 4: 455-466.

Avato, J. 2008. Portability of Social Security and Health Care Benefits in the United Kingdom. Background Paper for joint IDS/World Bank research project. Mimeo. [http://siteresources.worldbank.org/INTLM/Resources/3900411244141510600/Avato-UK.pdf]

Becker, Gary. 1964. Human Capital: A Theoretical and Empirical Analysis. New York: Colombia University Press.

Bonin, H., W. Eichhorst, C. Florman, M.O. Hansen, L. Skiöld, J. Stuhler, K.Tatsiramos, H. Thomasen and K.F. Zimmermann. 2008. "Geographic Mobility in the European Union: Optimising its Economic and Social Benefits”, IZA Research Report 19, Institute for the Study of Labour, Bonn.

Cornelissen, Rob. 2009. The European co-ordination of social security and third country nations”. In Danny Peters and Paul Schoukens. Eds. op.cit. 1-17.

Cruz, A. T. 2004. "Portability of Benefit Rights in Response to External and Internal Labour Mobility: The Philippine Experience,” Paper presented at the International Social Security Association (ISSA), Thirteenth Regional Conference for Asia and the Pacific in Kuwait, March 8-10. [http://www.issa.int/pdf/kuwait04/2cruz.pdf] [last accessed on October 22, 2008].

European Court for Human Rights (ECtHR). 2010. Case of Carlson and Others versus the United Kingdom (Application no. 42184/05). ECtHR : Strasbourg, 16. March 2010.

Eichenhofer, Eberhard. 2009. 50 Jahre nach ihrem Beginn - Neue Regeln für die Koordinierung sozialer Sicherheit, Jahrestagung des Europäischen Instituts für soziale Sicherheit (EISS) 26./27. September 2008, Berlin: Erich Schmidt Verlag.

Fabel. O. 1994. The Economics of Pensions and Variable Retirement Schemes. Chichester: Wiley.

Fenge, Robert and Jakob von Weizsaecker. 2009. Public pension systems and distortions of intra-EU mobility: the Lodge Test. Journal of Pension Economics and Finance 9 (2): 262-279.

Forteza, A. 2008. "The Portability of Pension Rights. General Principles and the Caribbean Case.” Social Protection Discussion Paper, No 0825. Washington, D.C.: The World Bank. [http://siteresources.worldbank.org/SOCIALPROTECTION/Resources/SPDiscussion-papers/Pensions-DP/0825.pdf].

Harteley, Gonzalo, Jan van Ours, and Milan Vodopinec. "Incentive Effects of Unemployment Insurance Savings Accounts: Evidence from Chile”. IZA Discussion Paper Series No. 4681, January. 
Hofmarcher, Maria, and Herta Rack. 2006. “Austria: Health System Review.” Health Systems in Transition, Vol. 8, No. 3.

Holzmann, Robert. 2005. "Toward a Reformed and Coordinated Pension System in Europe: Rational and Potential Structure.” In Robert Holzmann and Edward Palmer, eds. Pension Reform: Issues and Prospect for Non-Financial Defined Contribution (NDC) Schemes. Washington, D.C.: World Bank.

Holzmann, Robert, and Steen Lau Jorgensen. 2000. "Social Risk Management: A New Conceptual Framework for Social Protection and Beyond.” Social Protection Discussion Paper 0006, Human Development Network, World Bank, Washington, DC.

Holzmann, Robert, Johannes Koettl, and T. Chernetsky. 2005. "Portability Regimes of Pension and Health Care Benefits for International Migrants: An Analysis of Issues and Good Practices.” Social Protection Discussion Paper, No 0519. [http://siteresources.worldbank.org/SOCIALPROTECTION/Resources/SPDiscussion-papers/Pensions-DP/0519.pdf]

Holzmann, Robert, Edward Palmer and David Robalino. 2011. Eds. Non-Financial Defined Contribution (NDC) Pension Systems: Progress and New Frontiers in a Changing Pension World. World Bank: Washington, D.C. in print.

Holzmann, Robert and Yann Pouget. 2010a. Migration Management in the Mediterranean Region:Taking Stock, Reviewing, and Looking Ahead. Marseille Center for Mediterranean Integration, April.

Holzmann, Robert and Yann Pouget. 2010b. Social Protection for Temporary Migrant Workers: Conceptual Framework, Country Inventory, Assessment and Guidance. A Study prepared for the Global Forum of Migration and Development. Marseille Center for Mediterranean Integration, November.

Holzmann, Robert, David Robalino, and Nuriyuki Takayama. 2009. Eds. Closing the Coverage Gap: The Role of Social Pensions. World Bank: Washington, D.C.

Holzmann, Robert and Milan Vodopivec. 2011, eds. Reforming Severance Pay: An International Perspective. World Bank: Washington, D.C. in print

Hooghe, Mark, Ann Tappers, Bart Meuleman, and Tim Reeskens. 2008. Migration to European Countries: A structural Explanation of Patters, 1980-2004 (1). International Migration Review 42 (2).

International Labor Organization. 2009.: Protecting the Rights of Migrant Workers: A shared Responsibility. ILO: Geneva.

Kirdar, Murat. 2010. "Estimating the Impact of Immigrants on the Host Country Social Security System when Return Migration is an Endogenous Choice." IZA Discussion Paper, No. 4894.

Koettl, Johannes, Matteo Morghandi, and Alienor Van der Bosch. 2009. Social Portection Management for Migrants: The case of EU and North Africa. World Bank, mimeo.

Lazear, Edward. 1979. Why is there mandatory retirement? Journal of Political Economy 87: 1261-1284. 
Obermaier, Andreas. 2009. "Cross-border Purchase of Health Services. A Case Study on Austria and Hungary.” Policy Research Working Paper, No. 4825. World Bank.

Olivier, Marius. 2009. Regional Overview of Social Protection for Non-Citizens in the Southern African Development Community (SADC). Social Protection Discussion Paper, No 0908. [http://siteresources.worldbank.org/SOCIALPROTECTION/Resources/SPDiscussion-papers/Labor-Market-DP/0908.pdf]

Pieters, Danny. 2003. Ed. European Social Security and Global Politics. EESS Yearbook-Annuaire IESS 2001. The Hague/London/New York: Kluwer Law International.

Pieters, Danny and Paul Schoukens . 2009. Eds. The social security co-ordination between the EU and non-EU countries. Antwerp/Oxford/Portland: Intersentia.

Robalino, David and Andras Bodor. 2009. On the financial sustainability of earningsrelated pension schemes with "pay-as-you-go" financing and the role o government-indexed bonds. Journal of Pension Economics and Finance 8 (2), April: 153-187.

Sabates-Wheeler, Rachel. 2009. "Extending social security coverage: Good practices, lessons learnt and ways forward”. ISSA Working Paper No. 12.

Srban, Grega. 2009. "The existing bilateral and multilateral social security instruments bdining EU states and non-EU states.” In Danny Peters and Paul Schoukens. Eds. op.cit. 85-113.

Storesletten, K. 2003. "Fiscal Implications of Immigration - a Net Present Value Calculation.” Scandinavian Journal of Economics 105 (3), 487-506.

Sub, Wei, Anthony Webb and Natalia Zhivan. 2010. "Does staying healthy reduce your lifetime health costs?” Issue in Brief No. 10-8. Center for Retirement Research at Boston College, May.

Reitzes, M. and R. Sabates-Wheeler. 2008. "Navigating Social protection under a xenophobic State: Malawians in South Africa - evidence from the field". IDS.

United Nations (UN). 2006. "Trends In Total Migrant Stock: The 2005 Revision". Economics and Social Affairs, POP/DB/MIG/Rev.2005/Doc.

Valdes-Prieto, Salvador. Securitization of taxes implicit in PAYG pensions. Economic Policy 42, April: 217-251.

Verschueren, Herwig. 2009a. "New Provisions in Regulation 0003/2004 on Pensions and on Non-contributory Benefits", in 50 years of European Social Security Coordination, Leuwen: European Institute for Social Security.

Verschueren, Herwig. 2009b. "Social security co-ordniation in the agreements between the EU and Mediterranean countries, in particular turkey and the Maghreb countries. In Danny Peters and Paul Schoukens. Eds. op.cit. 19-55.

Werding, Martin. 2010. "Portability on Public Health Insurance: Conceptual Issues.” Presentation given at the Guidance Workshop on Establishing Portability: State of the Art, Key Issues, and Next Steps at the Marseille Center for Mediterranean Integration (CMI). Marseille, France: March 10. 
Werding, Martin and Stuart McLennan. 2010. "International Portability of Health Care Benefits: Concepts and Experience”. World Bank-Marseille Center for Mediterranean Integration. Discussion Draft, October.

World Bank. 2009. Country Classifications. [http://go.worldbank.org/D7SN0B8YU0]

World Bank. 2009. "Health Insurance and Competition." Report No. 44316-ECA. Washington, D.C.: World Bank.

Worldsalaries.org. 2010. International Average Salary Income Database: Austria. [http://www.worldsalaries.org/austria.shtml] 
Appendix Table A. Global migrant stock estimates and bilateral portability arrangement by origin and host region (2000)

\section{Host region}

\begin{tabular}{|c|c|c|c|c|c|c|c|c|c|c|}
\hline Origin & $\begin{array}{r}\text { East Asia and } \\
\text { Pacific } \\
\end{array}$ & $\begin{array}{r}\text { Eastern } \\
\text { Europe and } \\
\text { Central Asia }\end{array}$ & $\begin{array}{r}\text { EU-27 and } \\
\text { other Europe } \\
\end{array}$ & $\begin{array}{r}\text { Latin America } \\
\text { and } \\
\text { Caribbean } \\
\end{array}$ & $\begin{array}{r}\text { Middle East } \\
\text { and North } \\
\text { Africa } \\
\end{array}$ & $\begin{array}{r}\text { North } \\
\text { America } \\
\end{array}$ & South Asia & $\begin{array}{r}\text { Sub-Sahara } \\
\text { Africa } \\
\end{array}$ & Total & $\begin{array}{r}\% \text { global } \\
\text { stock }\end{array}$ \\
\hline $\begin{array}{l}\text { East Asia and } \\
\text { Pacific }\end{array}$ & $10,451,218$ & 261,715 & $2,397,524$ & 210,760 & $1,232,753$ & $7,960,615$ & 483,914 & 214,378 & $23,212,877$ & $12 \%$ \\
\hline $\begin{array}{l}\text { Eastern Europe } \\
\text { and Central Asia }\end{array}$ & 585,669 & $27,453,705$ & $8,437,718$ & 98,641 & $1,906,963$ & $1,618,709$ & 572,588 & 842,734 & $41,516,727$ & $22 \%$ \\
\hline $\begin{array}{l}\text { EU-27 and other } \\
\text { Europe }\end{array}$ & $2,611,118$ & $2,531,940$ & $13,106,560$ & $1,253,781$ & $1,118,468$ & $7,012,820$ & 387,166 & 859,007 & $28,880,860$ & $15 \%$ \\
\hline $\begin{array}{l}\text { Latin America } \\
\text { and Caribbean }\end{array}$ & 599,267 & 317,860 & $2,635,291$ & $3,746,076$ & 473,456 & $19,881,165$ & 394,517 & 296,351 & $28,343,983$ & $15 \%$ \\
\hline $\begin{array}{l}\text { Middle East and } \\
\text { North Africa }\end{array}$ & 373,298 & 308,571 & $5,322,781$ & 90,602 & $7,196,066$ & $1,395,416$ & 244,863 & 590,254 & $15,521,851$ & $8 \%$ \\
\hline North America & 426,299 & 65,989 & 806,774 & 754,313 & 167,834 & $1,250,399$ & 53,953 & 59,890 & $3,585,451$ & $2 \%$ \\
\hline South Asia & $1,001,521$ & 254,613 & $2,060,491$ & 48,931 & $8,660,674$ & $2,075,446$ & $10,779,215$ & 301,710 & $25,182,601$ & $14 \%$ \\
\hline $\begin{array}{l}\text { Sub-Sahara } \\
\text { Africa }\end{array}$ & 265,609 & 205,743 & $2,869,461$ & 42,855 & 860,137 & 977,764 & 254,197 & $14,795,580$ & $20,271,346$ & $11 \%$ \\
\hline $\begin{array}{r}\text { Total } \\
\% \\
\text { global stock }\end{array}$ & $16,313,999$ & $31,400,136$ & $37,636,600$ & $6,245,959$ & $21,616,351$ & $42,172,334$ & $13,170,413$ & $17,959,904$ & $186,515,696$ & $100 \%$ \\
\hline
\end{tabular}

Note: Regional country grouping according to World Bank terminology. See World Bank (2009).

Source: Avato, Koettl and Sabates-Wheeler (2009). 
Appendix Table B Global migrant stock estimates and bilateral portability arrangement by origin and host income-group (2000)

\begin{tabular}{|c|c|c|c|c|c|c|c|}
\hline \multirow[b]{2}{*}{$\begin{array}{l}\text { Origin country } \\
\text { income-group }\end{array}$} & \multicolumn{7}{|c|}{ Host country income-group } \\
\hline & $\begin{array}{r}\text { Low- } \\
\text { income } \\
\text { countries }\end{array}$ & $\begin{array}{r}\text { Lower } \\
\text { middle- } \\
\text { income } \\
\text { countries }\end{array}$ & $\begin{array}{r}\text { Upper } \\
\text { middle- } \\
\text { income } \\
\text { countries }\end{array}$ & $\begin{array}{r}\text { Non } \\
\text {-OECD high- } \\
\text { income } \\
\text { countries }\end{array}$ & $\begin{array}{r}\text { OECD high- } \\
\text { income } \\
\text { countries }\end{array}$ & Total & $\begin{array}{r}\% \text { global } \\
\text { stock }\end{array}$ \\
\hline $\begin{array}{l}\text { Low-income } \\
\text { countries }\end{array}$ & $23,339,921$ & $10,989,418$ & $4,832,109$ & $3,332,615$ & $11,128,178$ & $53,622,241$ & $29 \%$ \\
\hline $\begin{array}{l}\text { Lower middle- } \\
\text { income } \\
\text { countries }\end{array}$ & $4,817,600$ & $27,815,316$ & $9,099,077$ & $5,592,653$ & $29,162,504$ & $76,487,150$ & $41 \%$ \\
\hline $\begin{array}{l}\text { Upper middle- } \\
\text { income } \\
\text { countries }\end{array}$ & 691,741 & $2,095,454$ & $1,447,944$ & $1,110,490$ & $16,293,585$ & $21,639,214$ & $12 \%$ \\
\hline $\begin{array}{l}\text { Non-OECD high } \\
\text { income } \\
\text { countries }\end{array}$ & 195,520 & $1,270,164$ & 332,871 & 205,867 & $3,844,703$ & $5,849,125$ & $3 \%$ \\
\hline $\begin{array}{l}\text { OECD high- } \\
\text { income } \\
\text { countries }\end{array}$ & $1,147,634$ & $2,689,451$ & $1,721,117$ & 949,142 & $22,410,626$ & $28,917,970$ & $16 \%$ \\
\hline Total & $30,192,416$ & $44,859,803$ & $17,433,118$ & $11,190,767$ & $82,839,596$ & $186,515,700$ & $100 \%$ \\
\hline \% global stock & $16 \%$ & $24 \%$ & $9 \%$ & $6 \%$ & $44 \%$ & $100 \%$ & \\
\hline
\end{tabular}

Note: Regional country grouping according to World Bank terminology. See World Bank (2009).

Source: Avato, Koettl and Sabates-Wheeler (2009). 